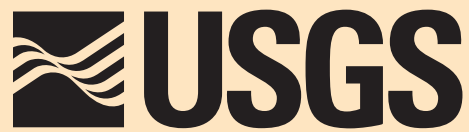

science for a changing world

\title{
Porosity-Depth Trends and Regional Uplift Calculated from Sonic Logs, National Petroleum Reserve in Alaska
}

Scientific Investigations Report 2005-5051 


\section{Porosity-Depth Trends and Regional Uplift Calculated from Sonic Logs, National Petroleum Reserve in Alaska}

By Philip H. Nelson and Kenneth J. Bird

Scientific Investigations Report 2005-5051 


\title{
U.S. Department of the Interior \\ Gale A. Norton, Secretary
}

\author{
U.S. Geological Survey \\ Charles G. Groat, Director
}

\section{U.S. Geological Survey, Reston, Virginia: 2005}

\author{
For sale by U.S. Geological Survey Information Services \\ Box 25286, Denver Federal Center \\ Denver, CO 80225 \\ This report and any updates to it are available online at: \\ http://pubs.usgs.gov/sir/2005/5051/ \\ For additional information write to: \\ U. S. Geological Survey \\ Box 25046, Mail Stop 421, Denver Federal Center \\ Denver, C0 80225-0046 \\ Additional USGS publications can be found at: \\ http://geology.usgs.gov/products.html \\ For more information about the USGS and its products: \\ Telephone: 1-888-ASK-USGS (1-888-275-8747) \\ World Wide Web: http://www.usgs.gov/
}

Any use of trade, product, or firm names in this publication is for descriptive purposes only and does not imply endorsement by the U.S. Government.

Although this report is in the public domain, it contains copyrighted materials that are noted in the text. Permission to reproduce those items must be secured from the individual copyright owners.

\section{Cataloging-in-Publication data are on file with the Library of Congress}

Produced in the Western Region, Menlo Park, California

Manuscript approved for publication, March 7, 2005

Text edited by George A. Havach

Layout and design by Stephen L. Scott 


\section{Contents}

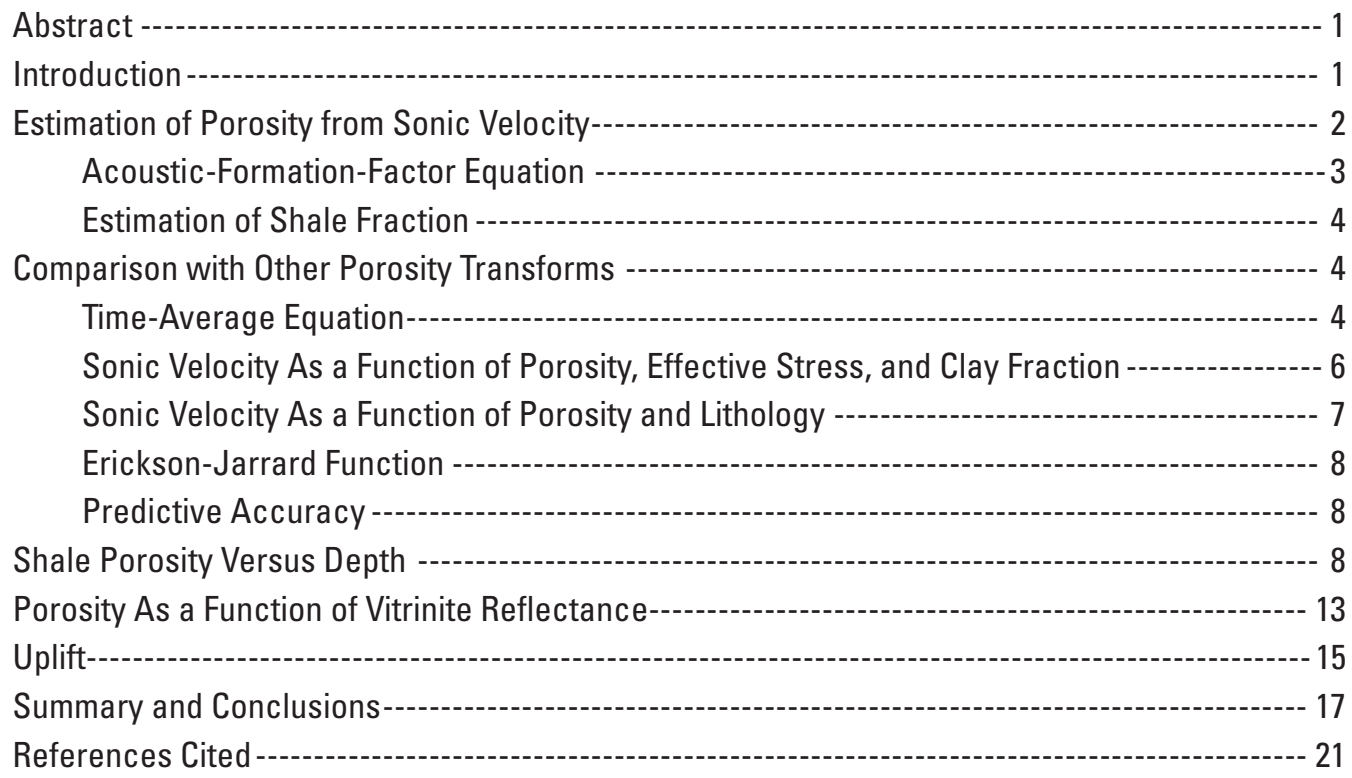

\section{Figures}

1. Map of the National Petroleum Reserve in Alaska, showing the locations of wells used

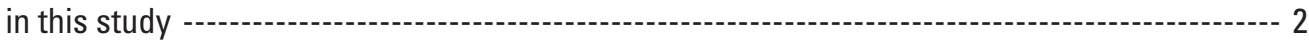

2. Plot of average porosity calculated from core data versus average sonic velocity calculated from sonic logs within 41 intervals in 16 wells drilled in the National Petroleum Reserve in Alaska

3. Plot of porosity versus depth, showing trendlines determined by Issler (1992) for five

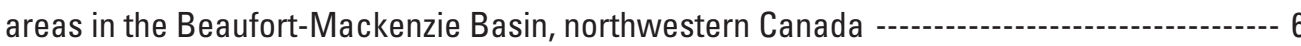

4. Plot of porosity versus depth in eight wells drilled into Tertiary and Cretaceous shales on the U.S. gulf coast, with porosity-depth trendlines determined by Issler (1992) for five areas in the Beaufort-Mackenzie Basin, northwestern Canada, shown for comparison

5. Plot of average porosity calculated from core data versus sonic velocity and traveltime calculated from sonic logs in 13 wells drilled in the National Petroleum Reserve in Alaska, with curves for sandstone and shale shown for comparison

6. Plot of average porosity calculated from core data versus sonic velocity and traveltime calculated from sonic logs in 13 wells drilled in the National Petroleum Reserve in Alaska, with curves for sandstone and shale and regression fits to laboratory measurements

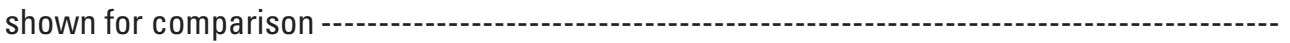

7. Plot of average porosity calculated from core data versus sonic velocity and traveltime calculated from sonic logs in 13 wells drilled in the National Petroleum Reserve in Alaska, with curves for sandstone and shale and regression fits to laboratory measurements on arenites, wackes, and shales shown for comparison 
8. Plot of average porosity calculated from core data versus sonic velocity and traveltime calculated from sonic logs in 13 wells drilled in the National Petroleum Reserve in Alaska, with curves for $0.0,0.5$, and 1.0 shale fractions shown for comparison

9. Plot of average porosity calculated from core data versus porosity calculated from sonic logs over the same intervals in 13 wells drilled in the National Petroleum Reserve in Alaska, referenced to ranges of gamma-ray values, with $y$-on- $x$ regression line and 1:1 line shown for comparison

10. Plot of average porosity calculated from core data versus porosity calculated from sonic logs over same intervals in 13 wells drilled in the National Petroleum Reserve in Alaska, referenced to depth ranges, with $y$-on- $x$ regression line and 1:1 line shown for comparison

11. Multiplot of electrical resistivity from deep induction log, of shale fraction calculated from gamma-ray log, and of porosity calculated from sonic log versus depth in the Phoenix well, National Petroleum Reserve in Alaska

12. Multiplots of electrical resistivity from deep induction logs, of shale fraction calculated from gamma-ray logs, and of porosity calculated from sonic logs versus depth in eight wells representative of areas A through $\mathrm{G}$ in the National Petroleum Reserve in Alaska ---- 11

13. Plot of average porosity in shales versus depth within the Torok Formation in wells drilled in coastal areas and offshore of the National Petroleum Reserve in Alaska, with porosity-depth trendlines determined by Issler (1992) for five areas in the BeaufortMackenzie Basin, northwestern Canada, shown for comparison

14. Plot of average porosity in shales versus depth within the Torok Formation in wells drilled in the foothills and central and western areas of the National Petroleum Reserve in Alaska, with porosity-depth trendlines determined by Issler (1992) for five areas in the Beaufort-Mackenzie Basin, northwestern Canada, shown for comparison

15. Plot of porosity loss in shales from top to bottom of the Torok Formation versus thickness of the Torok Formation in wells drilled in areas $A$ through $G$ in the National Petroleum Reserve in Alaska

16. Plot of average porosity in shales versus vitrinite reflectance in wells drilled in coastal areas of the National Petroleum Reserve in Alaska

17. Plot of average porosity in shales versus vitrinite reflectance in wells drilled in the foothills and central and western parts of the National Petroleum Reserve in Alaska

18. Map of the National Petroleum Reserve in Alaska, showing uplift estimated from porosity trends calculated from sonic logs in wells

19. Plot of uplift along the Barrow Arch estimated by three different methods: vitrinite reflectance, porosity trends calculated from sonic logs, and apatite fission-track analysis

\section{Tables}

1. Locations of wells drilled in the National Petroleum Reserve in Alaska in which porosity has been calculated from sonic logs

2. Sonic-log and core data from 46 intervals in 17 wells drilled in the National

Petroleum Reserve in Alaska

3. Values of coefficients in the acoustic-formation-factor equation--------------------------- 6

4. Porosities and estimated uplift in the Torok and Lower Torok Formations -----a- 20 


\title{
Porosity-Depth Trends and Regional Uplift Calculated from Sonic Logs, National Petroleum Reserve in Alaska
}

\author{
By Philip H. Nelson and Kenneth J. Bird
}

\section{Abstract}

Porosity decreases with depth in sedimentary basins, owing to the combined effects of compaction and cementation. The porosity profile in any individual well depends on the maximum effective stress, which is generally determined by the maximum burial depth. As a result, present-day porosity profiles can be interpreted in terms of maximum burial depth and subsequent uplift. Using sonic logs and porosity measurements in cored wells, we adapt a method of calculating porosity in siliciclastic rocks from sonic logs and compare it with several other algorithms relating sonic velocity and porosity. We then calculate porosity from sonic logs in wells within and adjacent to the National Petroleum Reserve in Alaska (NPRA).

Evaluating the shale-rich Early Cretaceous Torok Formation, we observe that the porosity-depth relation can be represented by one or two straight lines in each well. The porosity-depth lines are offset among wells in different areas within the northern NPRA, reflecting differences in uplift along the Barrow Arch. When the line segments are replotted in terms of porosity against vitrinite reflectance instead of present-day depth, the trends from areas within the coastal plain nearly coalesce, showing that the effect of maximum burial depth explains much, but not all, of the differences in the porosity profiles. Relative to a single offshore well where zero uplift is assumed to have occurred, estimates of uplift along the Barrow Arch range from less than 1,000 ft just east of the NPRA to 4,600 ft at Point Barrow. In the foothills of the southern NPRA, the computational method can provide only minimum estimates of uplift, which are less than, but compatible with, estimates of uplift based on the apatite fission-track method.

The porosity gradients in wells in the northern NPRA (coastal plain and near offshore) are similar to those in wells in other areas calculated by other workers: about 3 percent per 1,000 ft. In the southern NPRA (foothills), porosity gradients are lower than in the northern NPRA — that is, porosity decreases less rapidly with depth in the foothills (approx 1 percent per 1,000 ft) than in the coastal plain (max 12 percent per 1,000 ft). An explanation of the wide variation in porosity gradients in the NPRA awaits a better understanding of the evolution of pore pressure and effective stress within the context of the burial and uplift history of the Colville Basin.

\section{Introduction}

The goals of this study are to estimate present-day porosity as a constraint on basin-modeling efforts and to constrain estimates of regional uplift and erosion on the basis of the variation in porosity gradients.

In this study, we include data from all wells within the National Petroleum Reserve in Alaska (NPRA) that have sonic logs, a few wells close to the east boundary of the NPRA, and four offshore wells, for a total of 40 wells (fig. 1; table 1). Most wells within the NPRA were drilled during the years $1975-81$ by the U.S. Government. Well density is adequate along the north coastline and the southeastern NPRA but poor elsewhere, owing to the small number of wells and the absence of sonic logs in the early (1944-53) NPRA drilling program.

Core porosity measurements were available from 17 wells distributed over the NPRA and in one offshore well. The depth ranges and formation names are listed in table 2 , along with gamma-ray values and sonic traveltimes from well logs, averaged over the same depth ranges as the core data. Formations range in age from Mississippian to Cretaceous. Porosity measurements were included from clastic intervals but not from carbonates. Core porosities in unconfined samples from the Nanushuk Formation, Torok Formation, and Kemik Sandstone, all of Cretaceous age, were adjusted by multiplying the measured value by 0.86 , a reduction factor that we obtained from core tests on confined, stressed samples. Porosities in formations deeper than the Kemik Sandstone were not adjusted.

Sonic velocity is plotted against core porosity in figure 2 , keyed to formation. Younger (Brookian) sedimentary rocks plot below older (Ellesmerian) sedimentary rocks, and samples from the Kingak Shale fall between the two. The method of converting sonic well-log data to porosity is based on an analysis of the data plotted in figure 2 and listed in table 2.

The algorithm used by Issler (1992) for shales is extended herein to all siliciclastic rocks. Because several methods of converting sonic logs to porosity are available, we compare the algorithm used in this paper with others reported in the literature. After establishing a method of calculating porosity and comparing it with other methods, we next examine the porosity-depth trends in shales of the Torok 
Formation, a thick and areally extensive marine mudstone of Early Cretaceous age, with the purpose of estimating uplift and erosion within and adjacent to the NPRA.

Issler (1992) calculated porosity in shales from sonic logs and used the resulting porosity-depth trends to infer uplift and overpressure in the Beaufort-Mackenzie Basin of northwestern Canada, an area comparable in size to the NPRA. The plot of porosity versus depth in figure 3 summarizes the average porosity-depth trends for rocks of Late Cretaceous and Tertiary age in five areas of the Beaufort-Mackenzie Basin. Porosities in the inner delta (area 3), an area interpreted to have little or no uplift since the time of maximum burial, fall along the trend shown by the red curve. Porosities in the central and outer shelves (areas 1,2) are higher at a given depth than in the inner delta, a fact attributed to overpressuring caused by rapid deposition. Porosities in the main, western, and southern deltas (areas 4,5) are lower at a given depth than in the inner delta. The upward and leftward shift of the porosity-depth curves is attributed to uplift and erosion (arrow, fig. 3).

Other workers have used straight-line segments to represent porosity-depth trends in shales. Hunt and others (1998) presented porosity profiles in shales based on the uptake of an organic liquid by dried, evacuated shale cuttings. They demonstrated that, for porosities less than 35 percent, two straight-line segments provide a better fit to the data from Tertiary sections in the U.S. gulf coast than does a single exponential curve. The upper linear trends persist until the porosity decreases to about 10 percent; below this depth, shale porosity tends to remain constant (fig. 4). In two wells, Hunt and others calculated porosity gradients of 3.3 percent per $1,000 \mathrm{ft}$, close to those determined by Issler (1992). Porosity gradients in other wells plotted in figure 4 are as low as 1.04 percent per 1,000 ft.

\section{Estimation of Porosity from Sonic Velocity}

Sonic logs are generally presented in terms of "traveltime" $(\Delta t)$, which is a reciprocal velocity expressed in units of microseconds per foot. Other terms for traveltime are slowness and transit time. Traveltime is readily convertible to velocity; the sonic velocity $v$ is given by $10^{6} / \Delta t \mathrm{ft} / \mathrm{s}(304.8 / \Delta t \mathrm{~km} / \mathrm{s})$.

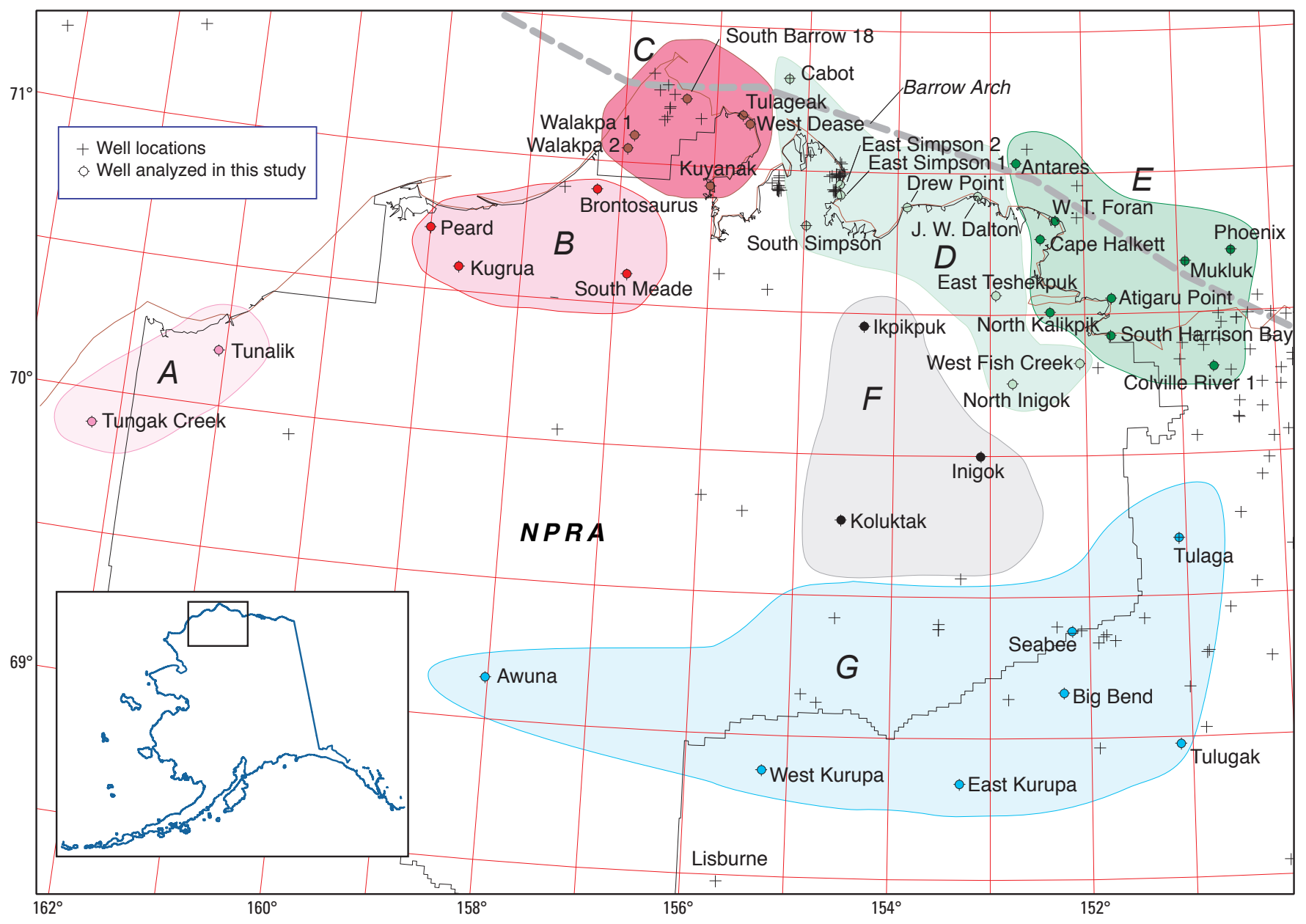

Figure 1. National Petroleum Reserve in Alaska (NPRA), showing locations of wells in areas A through $\mathrm{G}$ used in this study. 
Sonic logs are commonly used to estimate porosity, which is one of the rock parameters controlling sonic velocity. Many empirical expressions, sometimes called transforms, have been derived to relate sonic velocity and porosity in siliciclastic rocks. These empirical expressions satisfy available datasets but are not necessarily based on a physical model. In this report, we use a transform called the acoustic formation factor (AFF) to estimate porosity from sonic logs, and we compare this transform with some of the other transforms documented in the literature.

\section{Acoustic-Formation-Factor Equation}

A relation between traveltime and rock solidity, called the AFF equation, was proposed by Raiga-Clemenceau and others (1988):

$$
\frac{\Delta t_{\mathrm{m}}}{\Delta t}=\frac{v}{v_{\mathrm{m}}}=(1-\phi)^{x}
$$

where $\phi$ is the fractional porosity (the term $1-\phi$ represents the solid fraction of the rock), $x$ is an exponent to be determined from the data, and $\Delta t_{\mathrm{m}}$ and $v_{\mathrm{m}}$ are the matrix (zero porosity) traveltime and sonic velocity, respectively. The corresponding expression for porosity is

$$
\phi=1-\left(\frac{\Delta t_{\mathrm{m}}}{\Delta t}\right)^{\frac{1}{x}}
$$

As pointed out by Raiga-Clemenceau and others, equation 1 is functionally similar to the relation between electrical resistivity and porosity: it is simple in form, and it relates the velocity of a sonic wave to the solid fraction of the medium, rather than to the pore space. Raiga-Clemenceau and others tested equation 1 and listed the values of coefficients for porous reservoir rocks.

Equation 1 was applied by Issler (1992) in a study of compaction in siliciclastic rocks, predominantly shales, in the Mackenzie Delta of northern Canada, an area directly east of, and comparable in size to, the NPRA. Issler obtained laboratory measurements of porosity in shales and determined a value of 2.19 for the exponent $x$. Issler's form of equation 1 was subsequently used by Harrold and others (1999) in a study of pore pressure in mudrocks of Southeast Asia. In this report, we use a value of 2.19 for $x$.

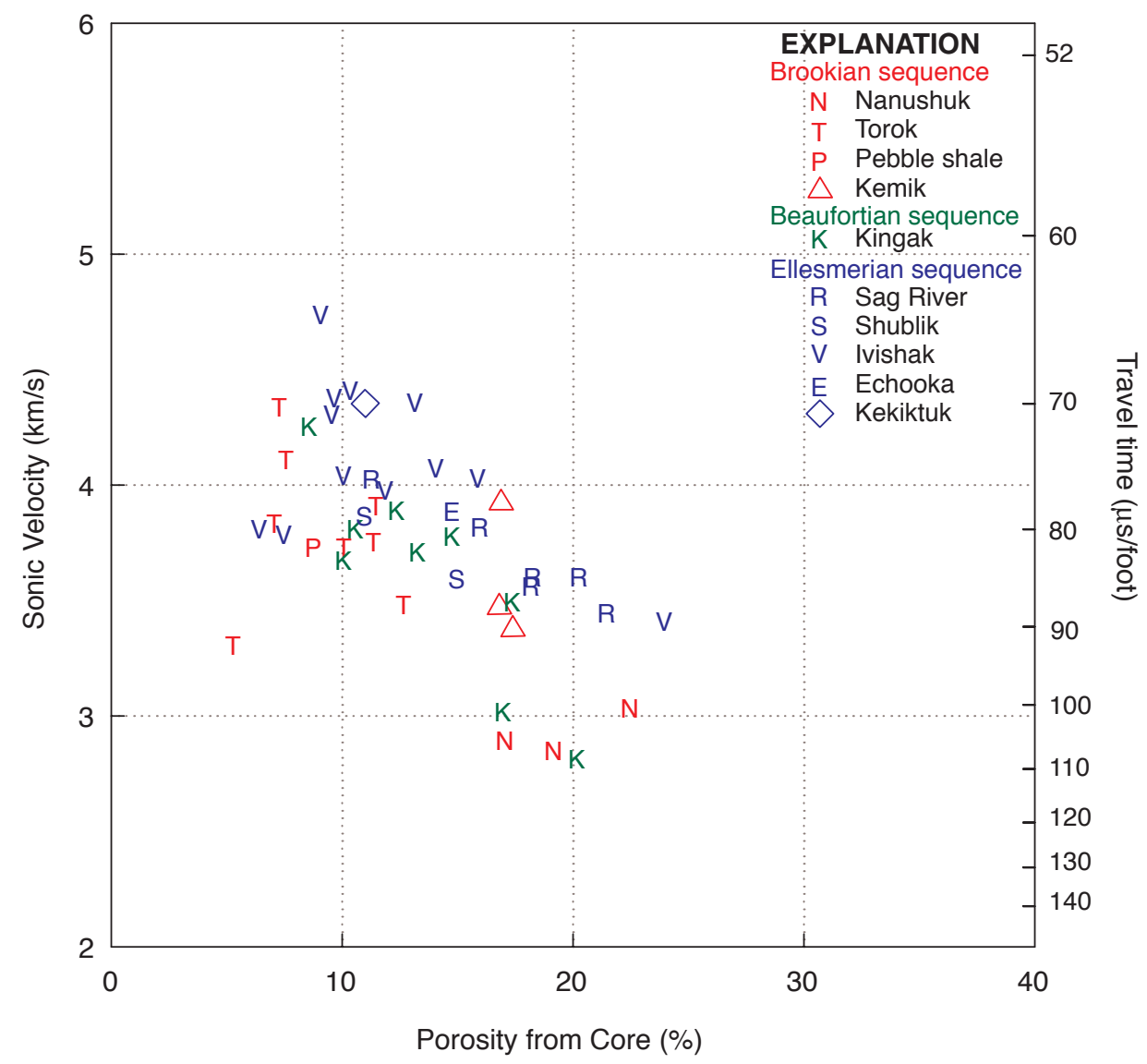

Figure 2. Average porosity calculated from core data versus average sonic velocity calculated from sonic logs within 41 intervals in 16 wells drilled in the National Petroleum Reserve in Alaska (see fig. 1 for locations). 
Table 1. Locations of wells drilled in the National Petroleum Reserve in Alaska in which porosity has been calculated from sonic logs.

[Data from Alaska Division of Oil and Gas, URL http://www.dog.dnr.state.ak.us/products/ data/Excel_files/www_well_lat_lon.xls]

\begin{tabular}{|c|c|c|c|}
\hline & Well No. and name & $\begin{array}{c}\text { Latitude } \\
\mathrm{N} .\end{array}$ & $\begin{array}{c}\text { Longitude } \\
\text { W. }\end{array}$ \\
\hline 1 & Antares 1 & $71.03598^{\circ}$ & $152.72372^{\circ}$ \\
\hline 2 & Atigaru Point ------ & $70.55612^{\circ}$ & $151.71707^{\circ}$ \\
\hline 3 & Awuna----------- & $69.15320^{\circ}$ & $158.02244^{\circ}$ \\
\hline 4 & Big Bend---- & $69.16196^{\circ}$ & $152.26711^{\circ}$ \\
\hline 5 & Brontosaurus-- & $70.90902^{\circ}$ & $157.24560^{\circ}$ \\
\hline 6 & Cabot & $71.32526^{\circ}$ & $155.21576^{\circ}$ \\
\hline 7 & Cape Halkett------- & $70.76740^{\circ}$ & $152.46673^{\circ}$ \\
\hline 8 & Colville River 1-- & $70.31165^{\circ}$ & $150.65390^{\circ}$ \\
\hline 9 & Drew Point --_- & $70.87976^{\circ}$ & $153.89997^{\circ}$ \\
\hline 10 & East Kurupa--_---_-_ & $68.84651^{\circ}$ & $153.31789^{\circ}$ \\
\hline 11 & East Simpson 1-- & $70.91778^{\circ}$ & $154.61799^{\circ}$ \\
\hline 12 & East Simpson 2--.- & $70.97861^{\circ}$ & $154.67387^{\circ}$ \\
\hline 13 & East Teshekpuk --.-. & $70.56992^{\circ}$ & $152.94362^{\circ}$ \\
\hline 14 & Ikpikpuk - & $70.45547^{\circ}$ & $154.33133^{\circ}$ \\
\hline 15 & Inigok-- & $70.00486^{\circ}$ & $153.09913^{\circ}$ \\
\hline 16 & J.W. Dalton --- & $70.92050^{\circ}$ & $153.13753^{\circ}$ \\
\hline 17 & Koluktak --- & $69.75250^{\circ}$ & $154.11110^{\circ}$ \\
\hline 18 & Kugrua --_-_-_-_- & $70.58702^{\circ}$ & $158.66203^{\circ}$ \\
\hline 19 & Kuyanak ----- & $70.93152^{\circ}$ & $156.03781^{\circ}$ \\
\hline 20 & Mukluk-------. & $70.68334^{\circ}$ & $150.91997^{\circ}$ \\
\hline 21 & North Inigok ----- & $70.25759^{\circ}$ & $152.76598^{\circ}$ \\
\hline 22 & North Kalikpik ------ & $70.50918^{\circ}$ & $152.36787^{\circ}$ \\
\hline 23 & Peard---_- & $70.71565^{\circ}$ & $159.00071^{\circ}$ \\
\hline 24 & Phoenix - & $70.71722^{\circ}$ & $150.42781^{\circ}$ \\
\hline 25 & Seabee - & $69.38015^{\circ}$ & $152.17534^{\circ}$ \\
\hline 26 & South Barrow 18 & $71.23972^{\circ}$ & $156.31142^{\circ}$ \\
\hline 27 & South Harrison Bay--.-- & $70.42297^{\circ}$ & $151.72795^{\circ}$ \\
\hline 28 & South Meade------ & $70.61498^{\circ}$ & $156.88260^{\circ}$ \\
\hline 29 & South Simpson -------- & $70.81242^{\circ}$ & $155.00005^{\circ}$ \\
\hline 30 & Tulaga --_- & $69.70390^{\circ}$ & $151.07579^{\circ}$ \\
\hline 31 & Tulageak - & $71.18934^{\circ}$ & $155.73357^{\circ}$ \\
\hline 32 & 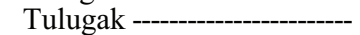 & $68.98481^{\circ}$ & $151.32976^{\circ}$ \\
\hline 33 & Tunalik - & $70.20596^{\circ}$ & $161.06915^{\circ}$ \\
\hline 34 & 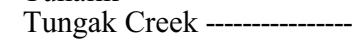 & $69.88390^{\circ}$ & $162.27319^{\circ}$ \\
\hline 35 & W.T. Foran-- & $70.82685^{\circ}$ & $152.28586^{\circ}$ \\
\hline 36 & Walakpa- & $71.09934^{\circ}$ & $156.88434^{\circ}$ \\
\hline 37 & Walakpa--_-_-_-_- & $71.05000^{\circ}$ & $156.95277^{\circ}$ \\
\hline 38 & West Dease - - & $71.15907^{\circ}$ & $155.62918^{\circ}$ \\
\hline 39 & West Fish Creek - & $70.32200^{\circ}$ & $152.06548^{\circ}$ \\
\hline 40 & West Kurupa---------- & $68.88295^{\circ}$ & $155.25497^{\circ}$ \\
\hline
\end{tabular}

The matrix traveltime, $\Delta t_{\mathrm{m}}$, can be either constant or a variable. Issler (1992) considered only the intervals of highest shale content, using a fixed value of $\Delta t_{\mathrm{m}}=\Delta t_{\mathrm{sh}}=67 \mu \mathrm{s} / \mathrm{ft}$. In this report, $\Delta t_{\mathrm{m}}$ varies with the shale fraction:

$$
\Delta t_{\mathrm{m}}=\left(1-V_{\mathrm{sh}}\right) \Delta t_{\mathrm{ss}}+V_{\mathrm{sh}} \Delta t_{\mathrm{sh}}
$$

where $\Delta t_{\mathrm{ss}}$ and $\Delta t_{\mathrm{sh}}$ are the traveltimes in zero-porosity sandstone and shale, respectively; and $V_{\text {sh }}$, the shale fraction, is derived from the gamma-ray log, as described in the next subsection. The average porosity calculated from core data is plotted against the average sonic velocity estimated from NPRA well logs in figure 5. The values of $\Delta t_{\mathrm{ss}}=52 \mu \mathrm{s} / \mathrm{ft}$ and $\Delta t_{\mathrm{sh}}=70$ $\mu \mathrm{s} / \mathrm{ft}$ were determined so that the curves for sandstone and shale bound the core data.

The usage of a $\Delta t_{\mathrm{m}}$ value that varies with shale fraction (eq. 2) allows the calculation of porosity in all rock types within the siliciclastic sequence. Lithology strongly influences porosity. For example, a traveltime of $76 \mu \mathrm{s} / \mathrm{ft}$ (righthand scale, fig. 5), which is equivalent to a sonic velocity of 4 $\mathrm{km} / \mathrm{s}$ (left-hand scale), transforms to a porosity of 4 percent in a shale end member and to a porosity of 16 percent in a sandstone end member. As the shale fraction ranges from 0 to 1 , equation 1 sweeps the area bounded by the curves for "sandstone" (AFF sandstone) and "shale" (AFF shale).

As just described, the values of the coefficients in equation 2 were adjusted to fit the core data, whereas the value of the exponent $x$ is from Issler (1992). The values of $x$ and $\Delta t_{\mathrm{m}}$ used in this report are compared with those from other sources in table 3 .

\section{Estimation of Shale Fraction}

The shale fraction, $V_{\mathrm{sh}}$, in siliciclastic rocks is estimated from the gamma-ray log, using the relation

$$
V_{\mathrm{sh}}=\frac{G R-G R_{\mathrm{sd}}}{G R_{\mathrm{sh}}-G R_{\mathrm{sh}}},
$$

where $G R$ is the logged gamma-ray value, and $G R_{\text {sd }}$ and $G R_{\text {sh }}$ are the gamma-ray values in sandstone and shale, respectively. Before applying this transform, the gamma-ray logs were inspected and corrected if offsets occurred between logging runs. Values of $G R_{\mathrm{sh}}$ (generally, 80-120 American Petroleum Institute [API] units) and $G R_{\text {sd }}(25-35)$ were then determined for each well from inspection of the well logs. The $V_{\text {sh }}$ value ranges from 0.0 to 1.0 . If a calculated $V_{\text {sh }}$ value exceeded 1.0 owing to the gamma-ray value exceeding the $G R_{\text {sh }}$ value, then the $V_{\text {sh }}$ value was set to 1.0 . The $V_{\text {sh }}$ parameter incorporates both clay and nonclay minerals.

\section{Comparison with Other Porosity Transforms}

\section{Time-Average Equation}

One of the first transforms relating velocity and porosity in siliciclastic rocks was proposed by Wylie and others (1956):

$$
\Delta t=(1-\phi) \Delta t_{\mathrm{m}}+\phi \Delta t_{\mathrm{f}}
$$

which states that the traveltime is the linear sum of the traveltimes in the solid and porous (fluid filled) fractions. This 
Table 2. Sonic-log and core data from 46 intervals in 17 wells drilled in the National Petroleum Reserve in Alaska.

[Sonic traveltimes and gamma-ray values are averaged over cored intervals ; porosities are averaged from laboratory measurements. Sonic velocity is traveltime converted to units of kilometers per second. Difference is between porosity calculated from sonic velocity and porosity measured in core samples]

\begin{tabular}{|c|c|c|c|c|c|c|c|c|c|c|}
\hline Atigaru Point---------- & Ivishak------- & 8,712 & 8,741 & 30 & 69.6 & 4.38 & 40 & 9.5 & 9.7 & -0.2 \\
\hline Awuna - - & Torok -- & 3,664 & 3,666 & 3 & 74.1 & 4.11 & 70 & 8.9 & 7.6 & 1.3 \\
\hline Drew Point --_-_-_- & Ivishak------------------- & 7,793 & 7,814 & 22 & 75.4 & 4.04 & 48 & 13.4 & 10.1 & 3.3 \\
\hline East Simpson 1 & Sag River ---_---- & 6,908 & 6,917 & 10 & 85.5 & 3.56 & 49 & 17.0 & 18.2 & -1.2 \\
\hline East Simpson 1 --_-- & Ivishak- & 7,466 & 7,522 & 44 & 69.1 & 4.41 & 33 & 10.8 & 10.4 & .4 \\
\hline East Simpson 2 & Nanushuk ------------- & 2,387 & 2,402 & 23 & 100.4 & 3.04 & 70 & 19.6 & 22.5 & -2.9 \\
\hline East Simpson 2 & Torok --------_------- & 6,057 & 6,083 & 25 & 81.1 & 3.76 & 73 & 10.9 & 11.4 & -.5 \\
\hline East Simpson 2 & Sag River ----_-------- & 6,705 & 6,735 & 31 & 84.6 & 3.60 & 41 & 18.0 & 20.3 & -2.3 \\
\hline East Simpson 2 & Kekiktuk --_-_-_-_--- & 7,248 & 7,277 & 30 & 70.0 & 4.35 & 30 & 11.9 & 11.0 & .9 \\
\hline Inigok -- & Nanushuk------------- & 2,632 & 2,656 & 6 & 105.2 & 2.90 & 84 & 19.8 & 17.1 & 2.7 \\
\hline Inigok - - & Nanushuk---_----_----- & 3,077 & 3,082 & 4 & 106.9 & 2.85 & 85 & 21.4 & 19.2 & 2.2 \\
\hline 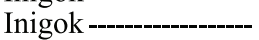 & Torok -- & 8,211 & 8,239 & 30 & 70.2 & 4.34 & 69 & 7.0 & 7.3 & -.3 \\
\hline Inigok - & Torok - & 8,849 & 8,851 & 3 & 79.4 & 3.84 & 78 & 10.9 & 7.1 & 3.8 \\
\hline J.W. Dalton----- & Ivishak--_----_---- & 7,965 & 8,013 & 37 & 74.8 & 4.07 & 66 & 8.8 & 14.1 & -5.3 \\
\hline J.W. Dalton-- & Ivishak-_-_-_-_-_-_-_-_ & 8,030 & 8,093 & 38 & 70.7 & 4.31 & 65 & 6.5 & 9.6 & -3.1 \\
\hline J.W. Dalton--_- & 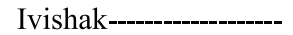 & 8,114 & 8,170 & 56 & 75.6 & 4.03 & 44 & 12.3 & 15.9 & -3.6 \\
\hline J.W. Dalton-- & Ivishak-------------- & 8,170 & 8,200 & 28 & 76.6 & 3.98 & 55 & 11.1 & 11.9 & -.8 \\
\hline Kuyanak---------------- & Kemik/Kuparuk C---- & 5,093 & 5,156 & 62 & 77.7 & 3.92 & 24 & 16.8 & 16.9 & -.1 \\
\hline Kuyanak---_-_--_- & Kingak/Barrow------- & 6,203 & 6,214 & 12 & 71.6 & 4.26 & 62 & 7.6 & 8.6 & -1.0 \\
\hline Peard - & Torok - & 3,034 & 3,058 & 5 & 87.5 & 3.48 & 67 & 15.6 & 12.7 & 2.9 \\
\hline Peard - & Torok --_---_-- & 5,409 & 5,419 & 8 & 81.7 & 3.73 & 60 & 14.0 & 10.1 & 3.9 \\
\hline Peard - & Kingak/Simpson ------ & 7,839 & 7,866 & 17 & 87.2 & 3.50 & 49 & 18.0 & 17.4 & .6 \\
\hline Peard --_-_-_-_-_-_.-_ & Echooka--- & 9,490 & 9,517 & 10 & 78.4 & 3.89 & 36 & 16.0 & 14.8 & 1.2 \\
\hline Tulageak -- & Shublik - & 3,800 & 3,815 & 16 & 78.8 & 3.87 & 57 & 12.5 & 11.0 & 1.5 \\
\hline Walakpa 1 -......... & Kemik/Kuparuk C---- & 2,071 & 2,081 & 11 & 87.8 & 3.47 & 40 & 19.7 & 16.8 & 2.9 \\
\hline Walakpa 1 --_----- & Kingak/Barrow------ & 3,051 & 3,096 & 26 & 80.6 & 3.78 & 47 & 15.7 & 14.8 & .9 \\
\hline Walakpa 2 & Kemik/Kuparuk C----- & 2,613 & 2,625 & 13 & 90.3 & 3.38 & 37 & 20.2 & 17.4 & 2.8 \\
\hline West Dease-_-_-_- & Kingak/Barrow------- & 3,700 & 3,730 & 31 & 78.3 & 3.89 & 50 & 12.7 & 12.4 & .3 \\
\hline West Dease------ & Kingak------------- & 3,730 & 3,791 & 29 & 82.9 & 3.68 & 66 & 11.8 & 10.1 & 1.7 \\
\hline West Dease--_-_-_-_- & Sag River ---- & 3,800 & 3,830 & 30 & 84.6 & 3.60 & 36 & 18.3 & 18.3 & .0 \\
\hline West Dease-------- & Shublik - & 3,831 & 4,003 & 61 & 84.8 & 3.59 & 53 & 15.2 & 15.0 & .2 \\
\hline
\end{tabular}

often-quoted relation is plotted in figure 5, where a value of $\Delta t_{\mathrm{f}}=189 \mu \mathrm{s} / \mathrm{ft}$ is used for the fluid and $\Delta t_{\mathrm{m}}=\left(1-V_{\mathrm{sh}}\right) \Delta t_{\mathrm{ss}}+V_{\mathrm{sh}} \Delta t_{\mathrm{sh}}$, as discussed in the previous subsection. At porosities less than 5 percent, the time-average equation is similar to the $\mathrm{AFF}$ equation, but they differ markedly for porosities greater than 15 percent.
Both the AFF and time-average equations are curvilinear on a plot of sonic velocity versus porosity (fig. 5). The slopes and intercepts depend on a parameter that is lithology dependent, namely, $\Delta t_{\mathrm{m}}$. Neither the AFF nor the time-average equation, however, depends explicitly on stress. The AFF sandstone and AFF shale curves in figure 5 span most of the 
Table 3. Values of coefficients in the acoustic-formation-factor equation.

\begin{tabular}{|c|c|c|c|}
\hline Rock or matrix type & Reference & $\begin{array}{c}\text { Matrix } \\
\text { traveltime } \\
(\mu \mathrm{s} / \mathrm{ft})\end{array}$ & $\begin{array}{c}\text { Exponent } \\
x\end{array}$ \\
\hline 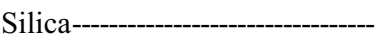 & Raiga-Clemenceau and others (1988) --_--- & 55.5 & 1.60 \\
\hline 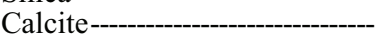 & Raiga-Clemenceau and others (1988) -------- & 47.6 & 1.76 \\
\hline Dolomite--_- & Raiga-Clemenceau and others (1988) ---_--- & 43.5 & 2.00 \\
\hline Mudstone, regression fit -.------ & Issler (1992) -- & 67.1 & 2.19 \\
\hline Mudstone, alternative fit --.--_- & Issler (1992) - - & 63.4 & 2.34 \\
\hline Mudstone and sandstone ---_---- & This report - & $52-70$ & 2.19 \\
\hline
\end{tabular}

core data, whereas several data points fall below the shale curve of Wylie and others (1956).

\section{Sonic Velocity as a Function of Porosity, Effective Stress, and Clay Fraction}

Using laboratory studies, numerous workers have determined linear relations between sonic velocity and porosity. Eberhart-Phillips and others (1989) analyzed velocity data on 64 water-saturated sandstones that were measured over a range of effective stress. The resulting relation shows that increases in both porosity $(\phi)$ and clay fraction $(C)$ both lead

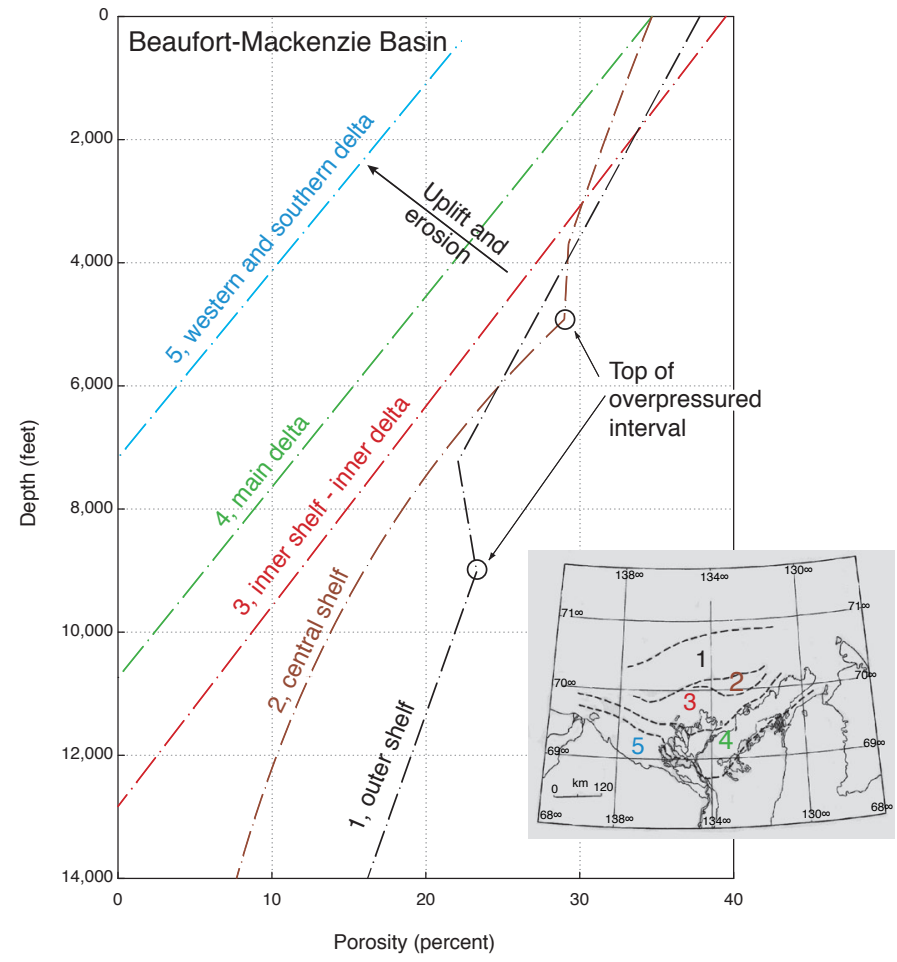

Figure 3. Porosity versus depth, showing trendlines determined by Issler (1992) for five areas (1-5) in the Beaufort-Mackenzie Basin, northwestern Canada. to a decrease in compressional velocity, $v_{\mathrm{p}}$ (in kilometers per second):

$$
v_{\mathrm{p}}=5.77-6.94 \phi-1.73 \sqrt{C}+0.446\left[P_{\mathrm{e}}-\exp \left(-16.7 P_{\mathrm{e}}\right)\right] .
$$

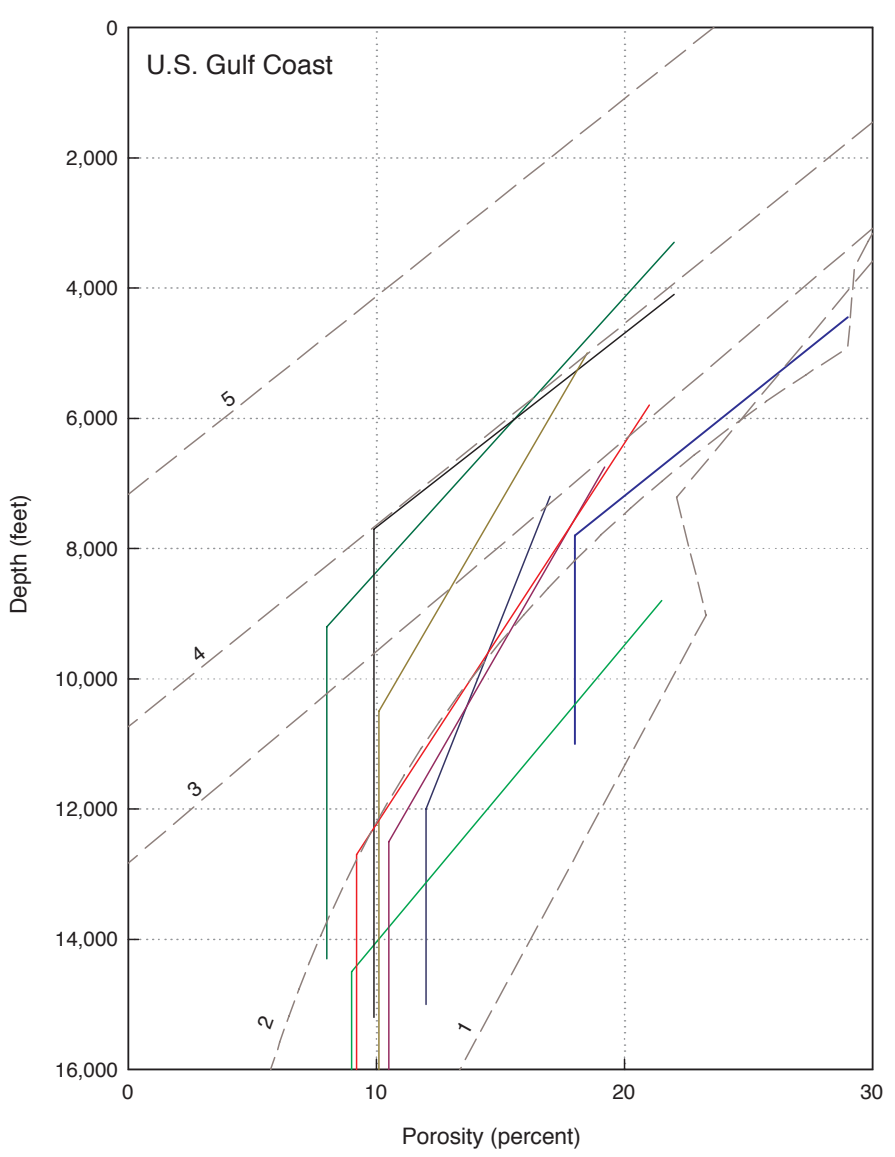

Figure 4. Porosity versus depth in eight wells (solid curves) drilled into Tertiary and Cretaceous shales on the U.S. gulf coast (from Hunt and others, 1998), with porosity-depth trendlines determined by Issler (1992) for five areas in the Beaufort-Mackenzie Basin, northwestern Canada (numbered dashed curves; see fig. 3), shown for comparison. Break in each curve represents point at which porosity ceases to decrease with depth. 
The effective stress, $P_{\mathrm{e}}$ (in kilobars), is the difference between the confining and hydrostatic stresses. The first term in equation $5,5.77 \mathrm{~km} / \mathrm{s}$, which is equivalent to a traveltime of $52.8 \mu \mathrm{s} / \mathrm{ft}$, represents the compressional velocity at zero porosity, zero clay fraction, and an effective stress of 12.5 MPa. At an effective stress of $0.125 \mathrm{kbars}$ (equivalent to $12.5 \mathrm{MPa}$ or $1,813 \mathrm{lb} / \mathrm{in}^{2}$ - if pore pressure is hydrostatic, this effective stress would be reached at a depth of about $3,250 \mathrm{ft}$, or slightly less than $1 \mathrm{~km}$ ), the fourth term is zero, and the remaining expression, dependent only on $\phi$ and $C$, takes on the values displayed in figure 6 . At effective stresses greater than $12.5 \mathrm{MPa}$, the family of black lines shifts to the right, so that at a given value of sonic velocity and clay fraction, the porosity is increased by 2,3 , and 4 percent at depths of about 5,000, 8,000, and 12,000 ft, respectively.

As a rule of thumb, clay constitutes 60 weight percent of an average shale (Hearst and others, 2000, p. 366). Thus, the 0.6 -clay-fraction line in figure 6 should be comparable to the "AFF shale" curve, and the 0.0-clay-fraction line and "AFF sandstone" curve both represent sandstones. At any given sonic velocity and clay (or shale) fraction, equation 5 yields higher estimates of porosity than does the AFF equation.

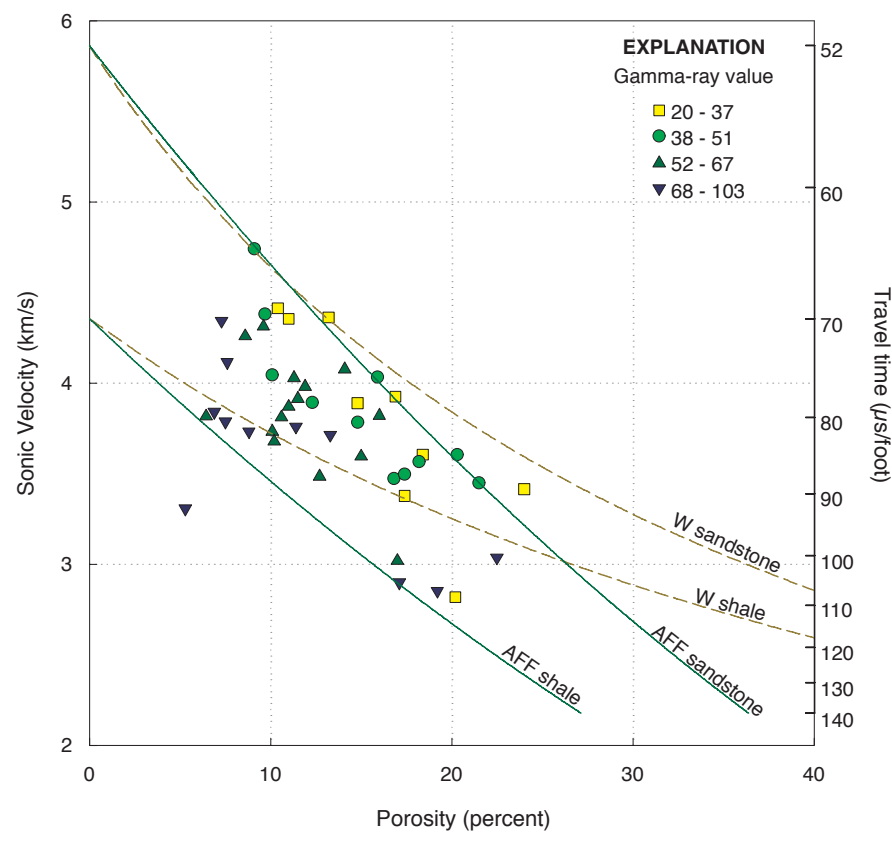

Figure 5. Average porosity calculated from core data versus sonic velocity and traveltime calculated from sonic logs in 13 wells drilled in the National Petroleum Reserve in Alaska (see fig. 1 for locations and table 2 for well data). Data points show ranges of gamma-ray values over same depth interval. AFF sandstone and AFF shale, curves for sandstone (shale fraction, 0.0 ) and shale (shale fraction, 1.0), as calculated with acoustic-formation-factor (AFF) equation; W sandstone and $W$ shale, curves calculated with time-average equation of Wylie and others (1956).

\section{Sonic Velocity as a Function of Porosity and Lithology}

Vernik and Nur (1992) and Vernik (1997) divided siliciclastic rocks into four classes on the basis of clay content and observed that the velocity-porosity relation is well described by linear functions (fig. 7). Their dataset incorporated the same samples used by Eberhart-Phillips and others (1989), as well as other samples. To eliminate the dependence on stress, they restricted their dataset to samples subjected to an effective stress of $40 \mathrm{MPa}$. The four classes of siliciclastic rocks and their clay contents are: clean arenites ( $<2-3$ weight percent), arenites ( $3-15$ weight percent), wackes (15-35 weight percent), and shales ( $>35$ weight percent).

Core data from NPRA wells lie well below the 0.0clay-fraction line in figure 6 and the "clean arenites" line in figure 7, indicating that the sample sets of Eberhart-Phillips and others (1989), Vernik and Nur (1992), and Vernik (1997) included higher-velocity samples than the NPRA samples. Thus, the field defined by the AFF equation used in this report (AFF sandstone and AFF shale curves, figs. 6, 7) is more restricted than the fields defined by those workers. There are two possible reasons for the absence of high-

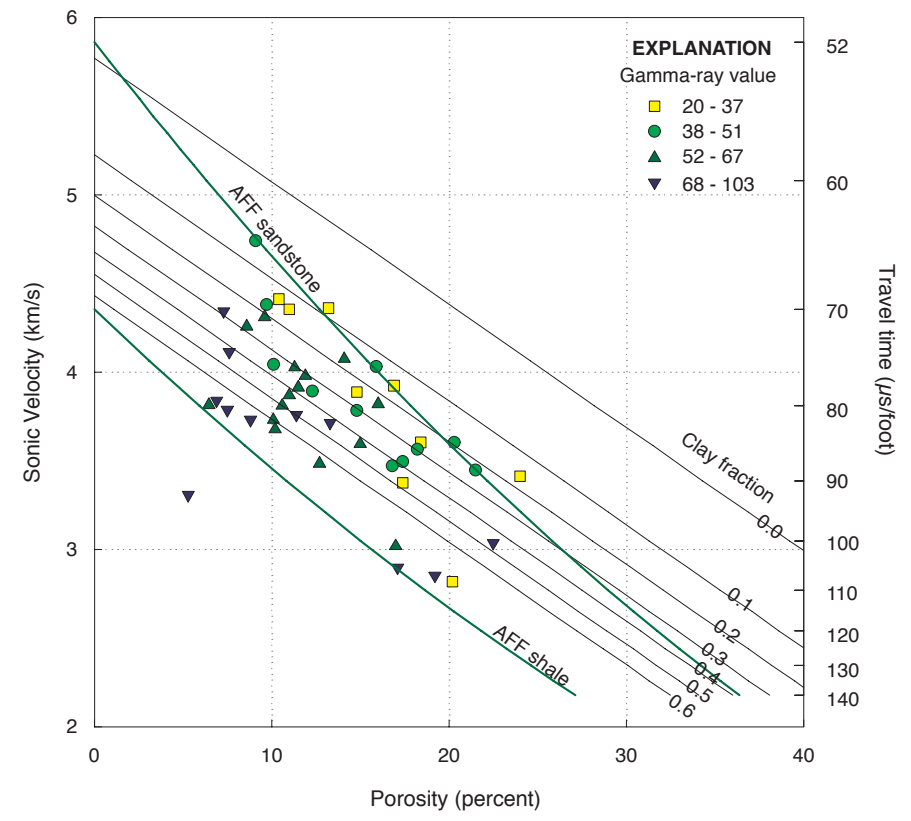

Figure 6. Average porosity calculated from core data versus sonic velocity and traveltime calculated from sonic logs in 13 wells drilled in the National Petroleum Reserve in Alaska (see fig. 1 for locations and table 2 for well data). Data points show ranges of gamma-ray values over same depth interval. AFF sandstone and AFF shale, curves for sandstone (shale fraction, 0.0 ) and shale (shale fraction, 1.0), as calculated with acoustic-formation-factor (AFF) equation; numbered straight lines, regression fit to laboratory measurements by EberhartPhillips and others (1989) at 12.5-MPa effective stress and various clay fractions $(0.0-0.6)$. 
velocity samples in the NPRA wells: (1) many of the cored intervals are at present-day depths less than $4,000 \mathrm{ft}$ (table 2) and thus are at effective stresses considerably less than $40 \mathrm{MPa}$, which is approximately equivalent to a burial depth of $10,500 \mathrm{ft}$; and (2) none of the cored intervals are dominated by low-clay arenites, as indicated by the average gamma-ray values listed in table 2. Figures 6 and 7 serve as reminders that the AFF equation, as defined in this report, is strongly conditioned by the availability of core data from NPRA wells.

\section{Erickson-Jarrard Function}

Using 23 experimental datasets and a set of empirical constraints, Erickson and Jarrard (1998) developed a transform that allows the calculation of sonic compressional velocity as a function of porosity and shale fraction (fig. 8). The functional form of their algorithm is rather ornate, and so the shale-dependent curves merge at a "critical point" porosity of 31 percent. The curves corresponding to the Erickson-Jarrard relation are similar to those of the AFF equation adopted for use in this report. The two shale-fraction lines (lowermost pair of lines, fig. 8) are virtually identical. The 0.5 -shale-fraction lines are similar over the porosity range $0-15$ percent, diverg-

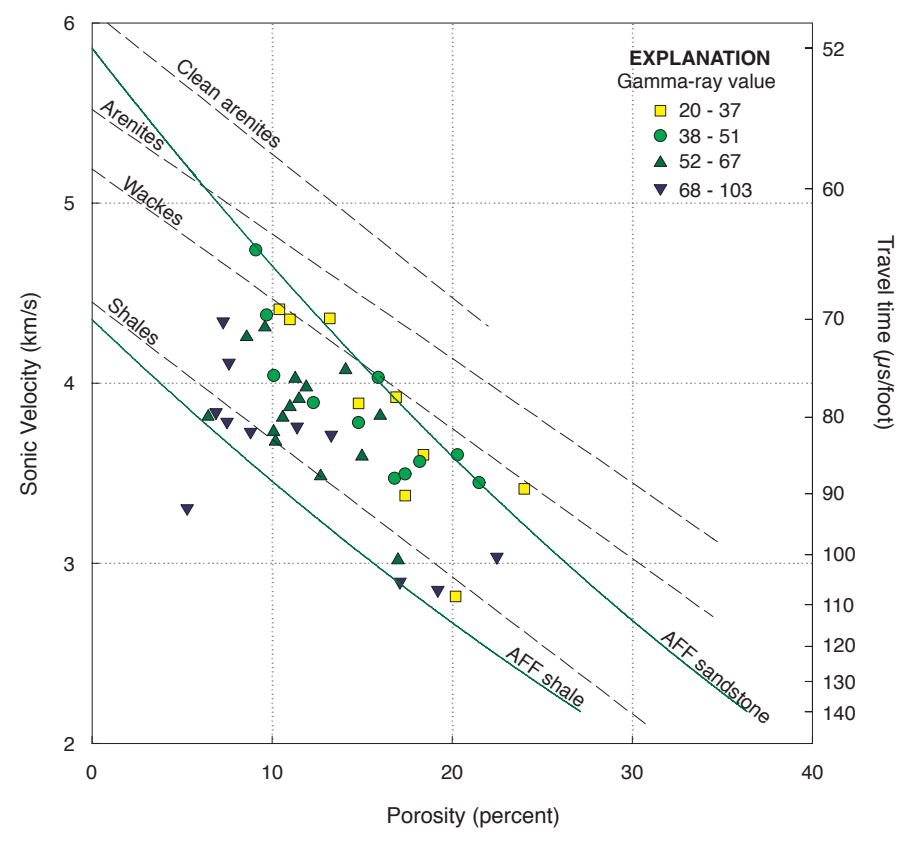

Figure 7. Average porosity calculated from core data versus sonic velocity calculated from sonic logs in 13 wells drilled in the National Petroleum Reserve in Alaska (see fig. 1 for locations and table 2 for well data). Data points show ranges of gamma-ray values over same depth interval. AFF sandstone and AFF shale, curves for sandstone (shale fraction, 0.0 ) and shale (shale fraction, 1.0), as calculated with acoustic-formation-factor (AFF) equation; dashed curves, regression fit to laboratory measurements on clean arenites, arenites, and wackes (Vernik and Nur, 1992) and on shales (Vernik, 1997) at 40-MPa effective stress. ing at higher porosities. At zero shale fraction (uppermost pair of lines), the slopes of the two lines differ, and so differences of -2 and +2 percent exist at 5.25 and $4.0 \mathrm{~km} / \mathrm{s}$, respectively.

Although sonic velocity can be calculated as a function of porosity and shale fraction from the Erickson-Jarrard relation, the complex form of their algorithm makes it difficult to calculate porosity from sonic velocity and shale fraction. The AFF equation, however, is easier to use. Though reassuring, the good match between the AFF equation and the Erickson-Jarrard relation, which is based on a collection of datasets, may be only coincidental.

\section{Predictive Accuracy}

The porosity calculated from the sonic log is compared with the average porosity measured from core samples in figures 9 (symbols corresponding to gamma-ray response) and 10 (symbols corresponding to depth of cored interval). The difference between the regression line and the one-to-one line indicates that, on a statistical basis, the AFF equation slightly underpredicts the high porosities and slightly overpredicts the low porosities. More significant are the vertical departures of individual points from the one-to-one line, which are equivalent to the differences listed in the right-hand column of table 2. Of the 46 data points, 12 values calculated from the sonic log differ from the core values by more than \pm 3 percent and 5 values differ by more than \pm 4 percent. Referring to figure 10 , depth dependence of porosity appears to be significant only for the shallowest (1,900-3,000-ft depth) samples: six of seven samples in the shallowest depth category lie above the one-to-one line, indicating that the AFF equation is likely to overpredict the true porosity at depths less than $3,000 \mathrm{ft}$.

\section{Shale Porosity Versus Depth}

The Torok Formation was selected for analysis of shale porosity versus depth because it is a thick, areally widespread, and relatively homogeneous lithologic unit. It represents a significant proportion of the Colville foreland-basin fill and is mid-Cretaceous (Aptian through Cenomanian) in age (Mull and others, 2003). As summarized by Molenaar (1988), it occurs throughout the NPRA, where it ranges in thickness from somewhat less than $900 \mathrm{~m}$ in the north to more than $6,000 \mathrm{~m}$ in the south. Uplift and erosion are indicated by surface exposures in the foothills of the Brooks Range and the occurrence of Torok rocks just beneath surficial Pliocene and (or) Pleistocene deposits on the Barrow peninsula (area C, fig. 1).

The Torok Formation is characterized by clinoform seismic geometry. Where completely preserved, the seismic reflectors indicate that approximately the upper tenth of the Torok represents shelf environments, the middle $40-60$ percent slope environments, and the lowermost 30-50 percent basinal environments. Turbidite sandstones are most common in the lowermost part of slope and in the basinal settings. The 
Torok Formation is the lateral equivalent of the fluvial-deltaic Nanushuk Formation and, in its lowermost and southernmost parts, probably equivalent to the Fortress Mountain Formation. Wells located south of lat $70^{\circ} \mathrm{N}$., except for the Tulaga (area G, fig. 1), were drilled on anticlines in which the Torok is structurally thickened by some combination of thrust faulting and shale flowage. The anticlines were formed in early Tertiary time (60-45 Ma), according to apatite fission-track analysis (Potter and Moore, 2003).

A modest sampling (18 samples from 11 wells; BartschWinkler and Huffman, 1988) indicates that Torok sandstones are composed, on average, of 54 volume percent quartz, 18 volume percent feldspar, and 28 volume percent lithic grains. Lithic grains are represented, on average, by 24 volume percent volcanic-rock, 17 volume percent metamorphic-rock, and 59 percent sedimentary-rock grains. In addition, Torok sandstones were determined to contain from 10 to more than 30 percent clayrich matrix, believed to be composed of mudstone and siltstone grains that have been molded between more resistant grains, so that they have lost their original shape identifying them as detrital grains.

Porosity was calculated from sonic logs in 40 wells penetrating most or all of the Torok Formation within and immediately adjacent to the NPRA (fig. 1; table 1). First, the shale fraction was calculated from the gamma-ray $\log$ (shale-fraction

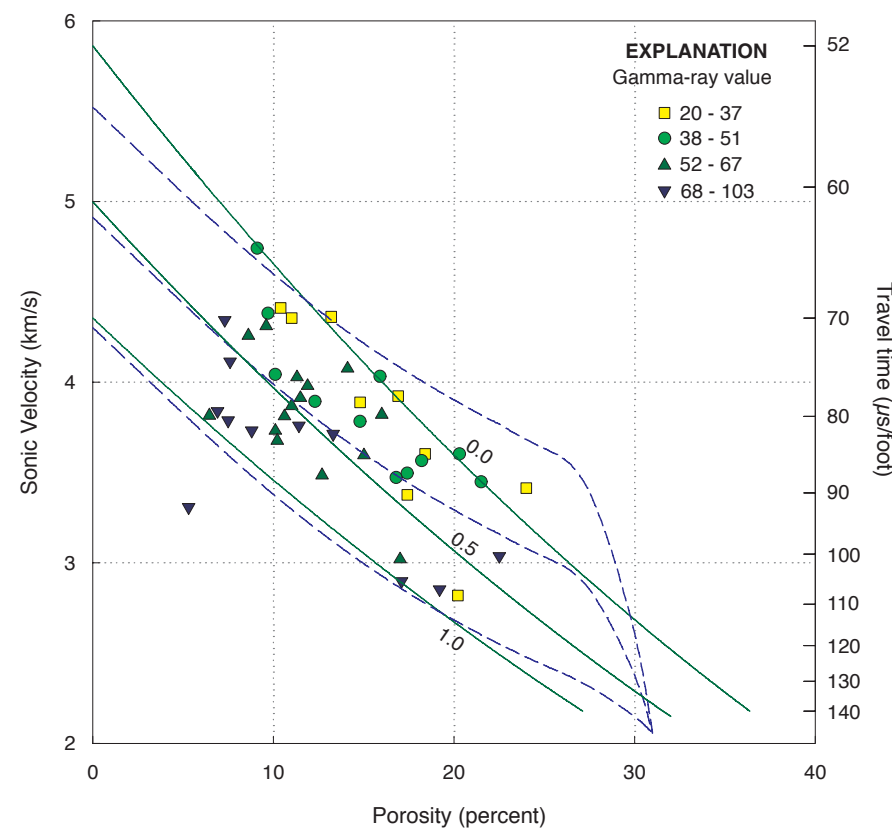

Figure 8. Average porosity calculated from core data versus sonic velocity and traveltime calculated from sonic logs in 13 wells drilled in the National Petroleum Reserve in Alaska (see fig. 1 for locations and table 2 for well data), with curves for shale fractions of $0.0,0.5$, and 1.0 calculated with acoustic-formation-factor (AFF) equation (solid curves) and with normal consolidation model of Erickson and Jarrard (1998) (dashed curves) shown for comparison. Data points show ranges of gamma-ray values over same depth interval.

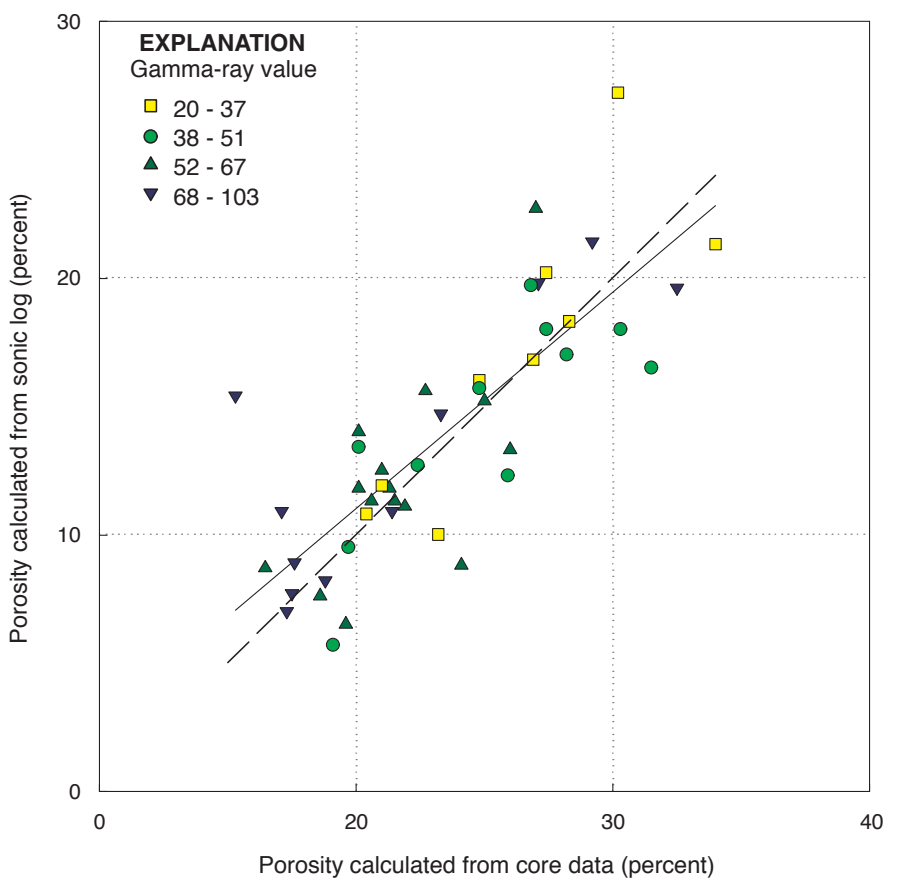

Figure 9. Average porosity calculated from core data versus porosity calculated from sonic logs over same intervals in 13 wells drilled in the National Petroleum Reserve in Alaska (see fig. 1 for locations and table 2 for well data), referenced to ranges of gamma-ray values, with $y$-on- $x$ regression line (solid curve) and 1:1 line (dashed curve) shown for comparison. Symbols indicate ranges of gamma-ray values.

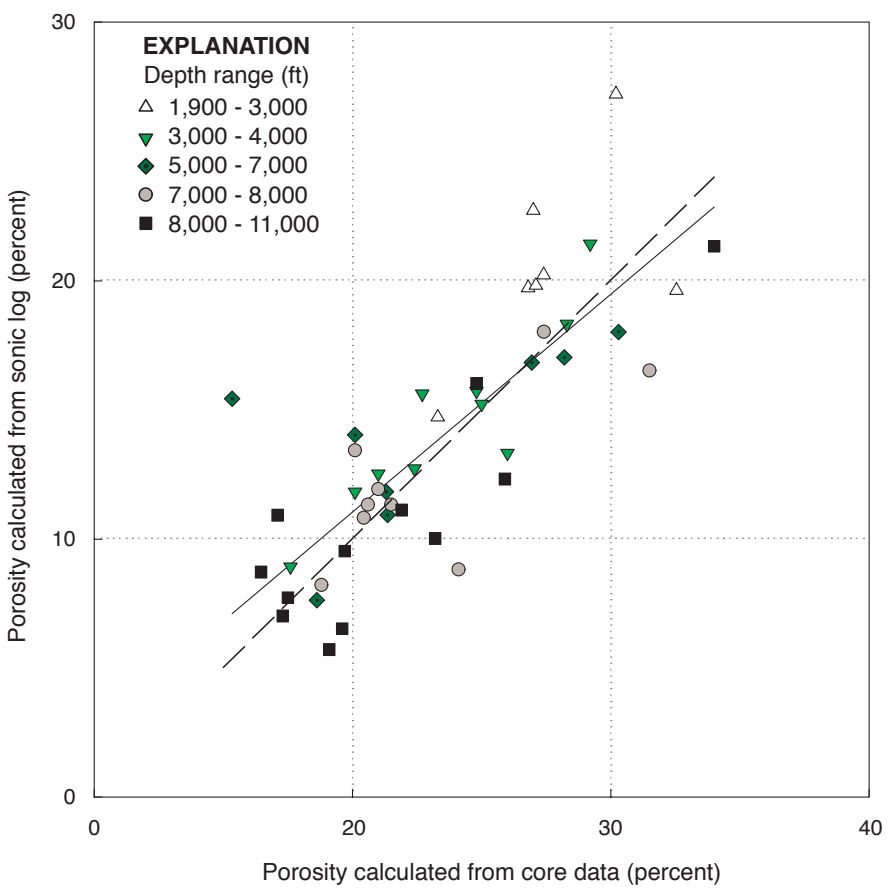

Figure 10. Average porosity calculated from core data versus porosity calculated from sonic logs over same intervals in 13 wells drilled in the National Petroleum Reserve in Alaska (see fig. 1 for locations and table 2 for well data), referenced to depth ranges, showing $y$-on- $x$ regression line (solid curve) and 1:1 line (dashed curve). 
curves, figs. 11, 12). Then the porosity was calculated from the sonic log, using equations 1 and 2 . Both filtered (smoothed) and unfiltered forms are shown in figure 12. Porosity decreases with depth throughout the Brookian sequence $(1,000-7,400-\mathrm{ft}$ depth, fig. 11). From 1,000- to 5,500-ft depth, the porosity in sandier (low shale fraction) intervals is greater than in shalier (high shale fraction) intervals, as also determined by Rowan and others $(2002,2003)$ in wells offshore the North Slope of Alaska. Commencing some $500 \mathrm{ft}$ above the top of the Torok Formation, however, the relation reverses, and the porosity in sandier units is less than in shalier units. This reversed relation is observed in the Torok Formation in all the wells that we have studied, as shown by the examples in figure 12. (The trend in the overpressured Tunalik well in fig. $12 \mathrm{~A}$ does not show a reversed relation.)
The bulk of the Torok Formation is composed of finegrained sandstone, siltstone, and mudstone. Few sandstone intervals are thick enough to be discernible on the gamma-ray $\log$, and those that are recognizable have gamma-ray values not much lower than those of the siltstones and mudstones. Torok sandstones are reported to contain low-grade metasedimentaryrock fragments (David Houseknecht, oral commun., 2004) and are known to have high feldspar and lithic-grain contents, which cause elevated gamma-ray values that would result in a low calculated porosity (eqs. 1, 2). In addition, Torok sandstones in outcrop are observed to be well cemented (Chris Schenk, oral commun., 2002). From these observations, the low porosities calculated in sandier units of the Torok Formation could be due to a combination of elevated gamma-ray values and a high degree of cementation.

\section{Phoenix}

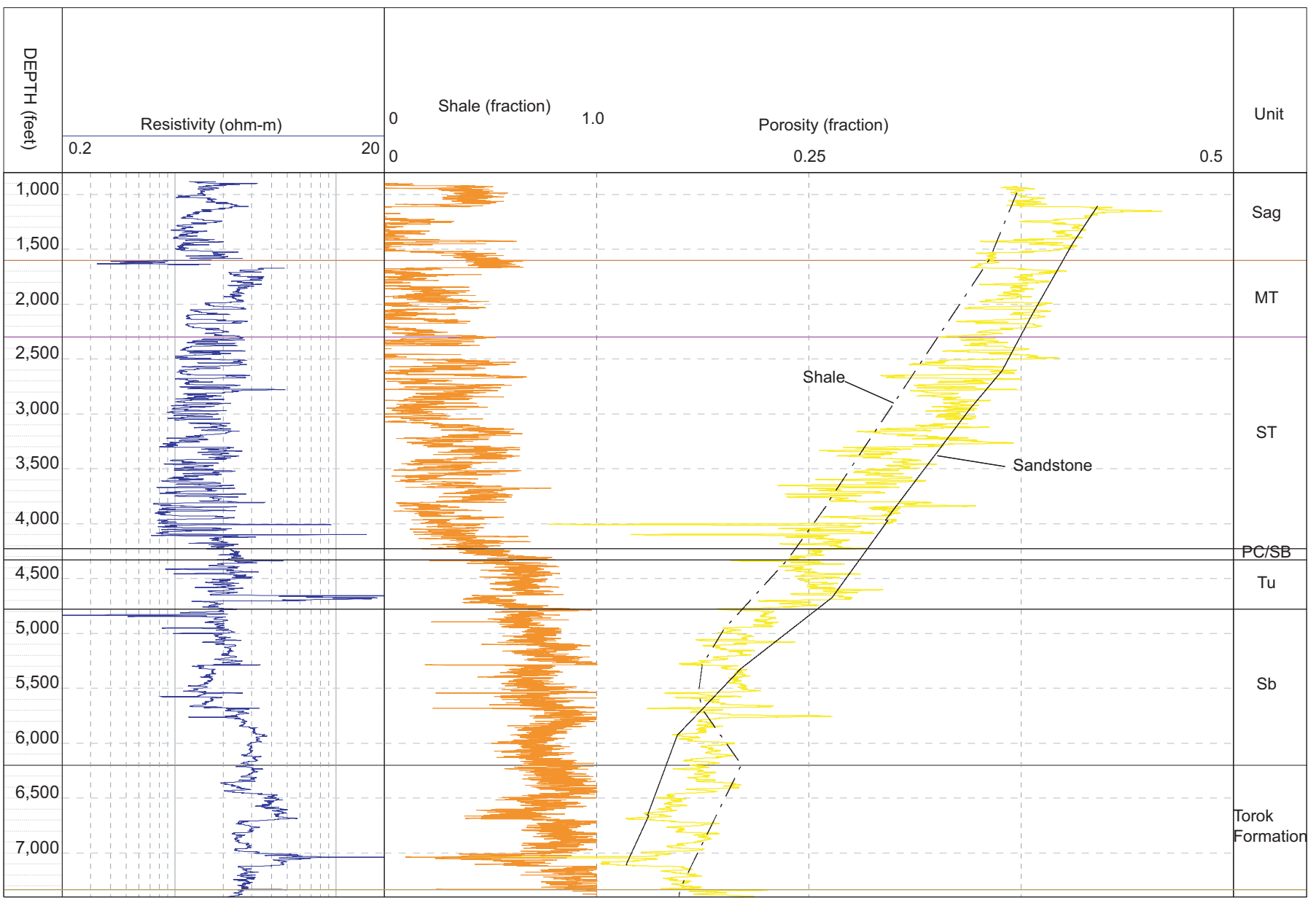

Figure 11. Electrical resistivity from deep induction log, shale fraction calculated from gamma-ray log, and porosity calculated from sonic log versus depth in the Phoenix well in area E, National Petroleum Reserve in Alaska (see fig. 1 for location and table 2 for well data). Solid irregular curve labeled "sandstone" tracks porosity in sandiest intervals, and dashed irregular curve labeled "shale" tracks porosity in shaliest intervals. Relation between porosity in sandstone and shale reverses at about $500 \mathrm{ft}$ above top of the Torok Formation. Brookian units above the Torok Formation: MT, Mikkelsen Tongue of the Canning Formation; PC/SB, Prince Creek/Shrader Bluff Formation, undifferentiated; Sag, Sagavanirktok Formation; Sb, Seabee Formation; ST, Staines Tongue of the Sagavanirktok Formation; Tu, Tuluvak Formation. 
To compare the porosity-depth trends in shales from different wells, it is desirable to select a line representing the shale edge of the porosity-depth curve. We chose to represent shale porosity with a two-point linear fit within the Torok Formation for each well, as illustrated in figure 12, whereas Rowan and others $(2002,2003)$ used exponential relations to represent the porosity-depth relations for both sandstones and shales throughout the Brookian section. Exponential relations are generally used when seeking a single equation to represent the porositydepth relation for various geologic formations within an entire basin. To represent the porosity-depth relation for the Torok Formation within individual wells, however, a linear fit was determined to be sufficient.

The two depth points were chosen with several considerations in mind: representation of shaly rather than sandy sequences, adequate depth separation to minimize errors in calculating the slope, avoidance of enlarged or rough wellbore where the sonic traveltime may be erroneous, and avoidance of zones that may be overpressured. Zones of high organic-carbon content were also avoided, although such zones are rare within

$12 A$

Tunalik 1

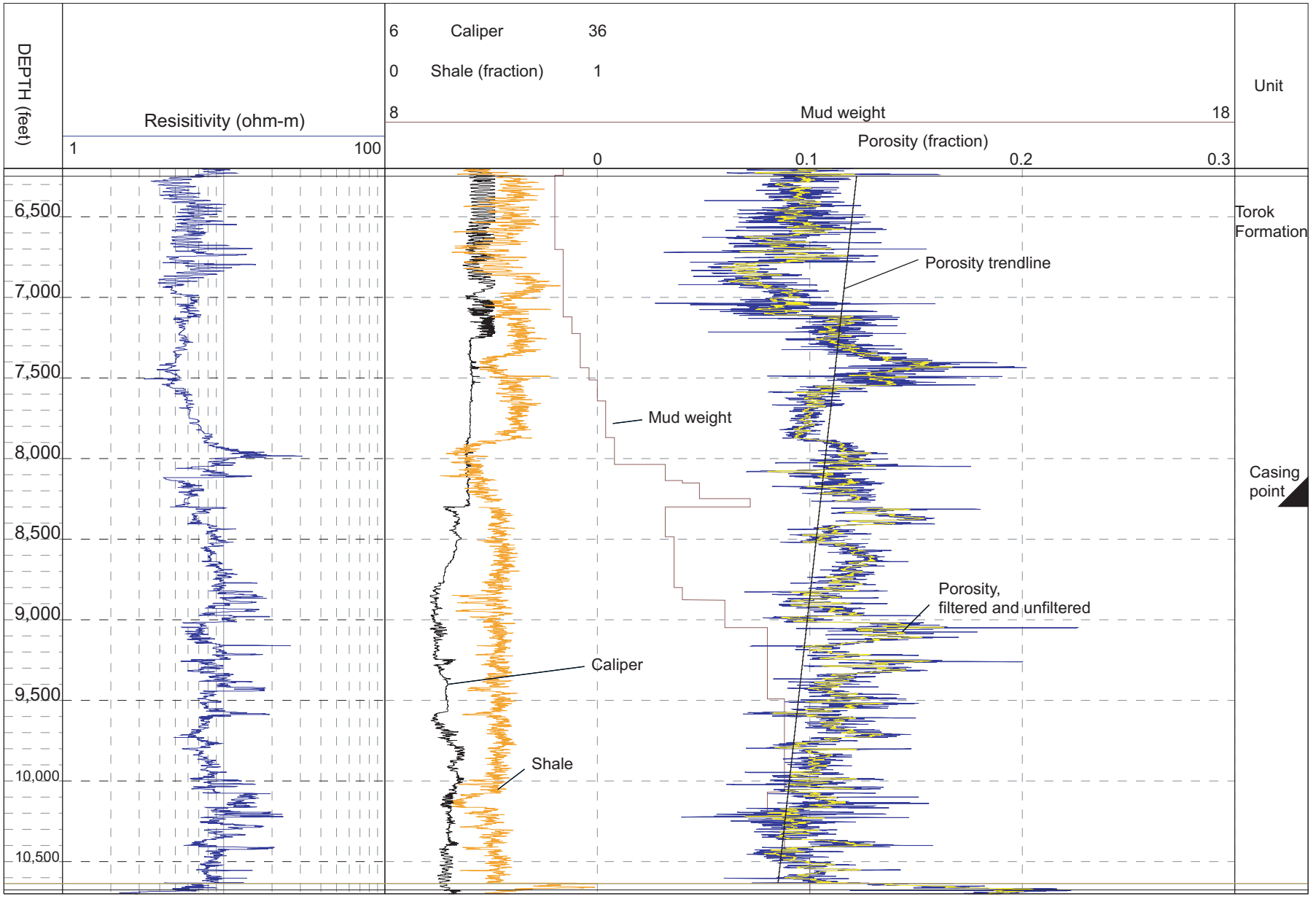

Figure 12. Electrical resistivity from deep induction logs, shale fraction calculated from gamma-ray logs, and porosity (blue, unfiltered; yellow, filtered) calculated from sonic logs (using acoustic-formation-factor equation; see text) versus depth in eight wells representative of areas $A$ through G, National Petroleum Reserve in Alaska (see fig. 1 for locations and table 2 for well data), with caliper and mud weight shown for reference. Porosity-depth curve is drawn for shaliest parts of the Torok Formation. $A$, Tunalik well (area A). Mud weight indicates overpressure. Drillbit spiraled in interval from 6,250- to 7,250-ft depth, which is out of gauge. $B$, Peard well (area B). Mud weight indicates normal pressure. Exceptionally high gamma-ray value at 5,810-ft depth gives an erroneously high porosity. C, Kuyanak well (area C). Mud weight indicates normal pressure. $D$, J.W. Dalton well (area D). Mud weight indicates normal pressure. E, South Harrison Bay well (area E). Mud weight and hydraulic-pressure gradient (calculated from drillstem tests) indicate near-normal pressure. F, Phoenix well (area E). Mud weight indicates normal pressure. G, Inigok well (area F). Mud weight indicates normal pressure. $H$, Tulugak well (area G). Mud weight indicates some overpressure. Well penetrated 8,000 ft of the Lower Torok Formation (not shown), requiring mud weights as high as $15.7 \mathrm{lb} /$ gal. Drillstem test through perforated intervals between 7,898and 8,571-ft depth produced light gas flow to surface at a hydraulic-pressure gradient of $0.48 \mathrm{lb} / \mathrm{in}^{2}$ per foot. 
the Torok Formation. The porosities at each of the two depth points were averaged over depth intervals ranging from 10 to $100 \mathrm{ft}$, depending on the characteristics of the calculated porosity-depth curve. The porosity gradient (percent porosity change per 1,000 ft of depth) of the two-point line segment was calculated from the differences between the average porosities and the depths at the two points (table 4). The line was extrapolated to the top and bottom of the Torok Formation, as indicated in figure 11; the porosities and depths for each well are listed in table 4 .

Porosity trendlines for all wells are plotted in figures 13 and 14, coded according to area. All the trendlines from wells in the coastal area and offshore (fig. 13) fall within the average trendlines compiled by Issler (1992) for areas 3 through 5 in the Mackenzie Delta (fig. 3). Trendlines for the easternmost wells plot deeper than those for all the others, indicating that the strata in these wells have been uplifted less than in wells to the west (compare fig. 3). Except for the high porosity gradients in area $\mathrm{C}$, the gradients of the trendlines in figure 13 are similar to the gradients of Issler's average trendlines.
In contrast, the porosity trendlines for all wells in the foothills, central, and western areas (fig. 14) do not match the average trendlines established by Issler (1992). Some of these trendlines are composed of two line segments, in which the lower line segment represents the porosity trend in the lower Torok/Fortress Mountain depositional sequence. The very steep trendlines displaying low porosity gradients in figure 14 indicate a different compaction history than that manifested in the wells in figure 13. Issler observed low porosity gradients in offshore environments of the Beaufort-Mackenzie Basin where overpressure exists today, as shown by the curves for areas 1 and 2 in figures 3 and 14.

Because overpressure reduces the effective stress, the porosity at a given depth remains greater than if the hydrostatic pressure were normal. Magara (1978) stated that the signature of overpressured conditions remains in the sonic logs; that is, the sonic velocity remains low even after the rocks have been uplifted and the hydraulic pressure has returned to normal. Much of the increase in sonic velocity with compaction and cementation is permanent, resulting in a hysteresis effect

\section{$12 B$}

Peard 1

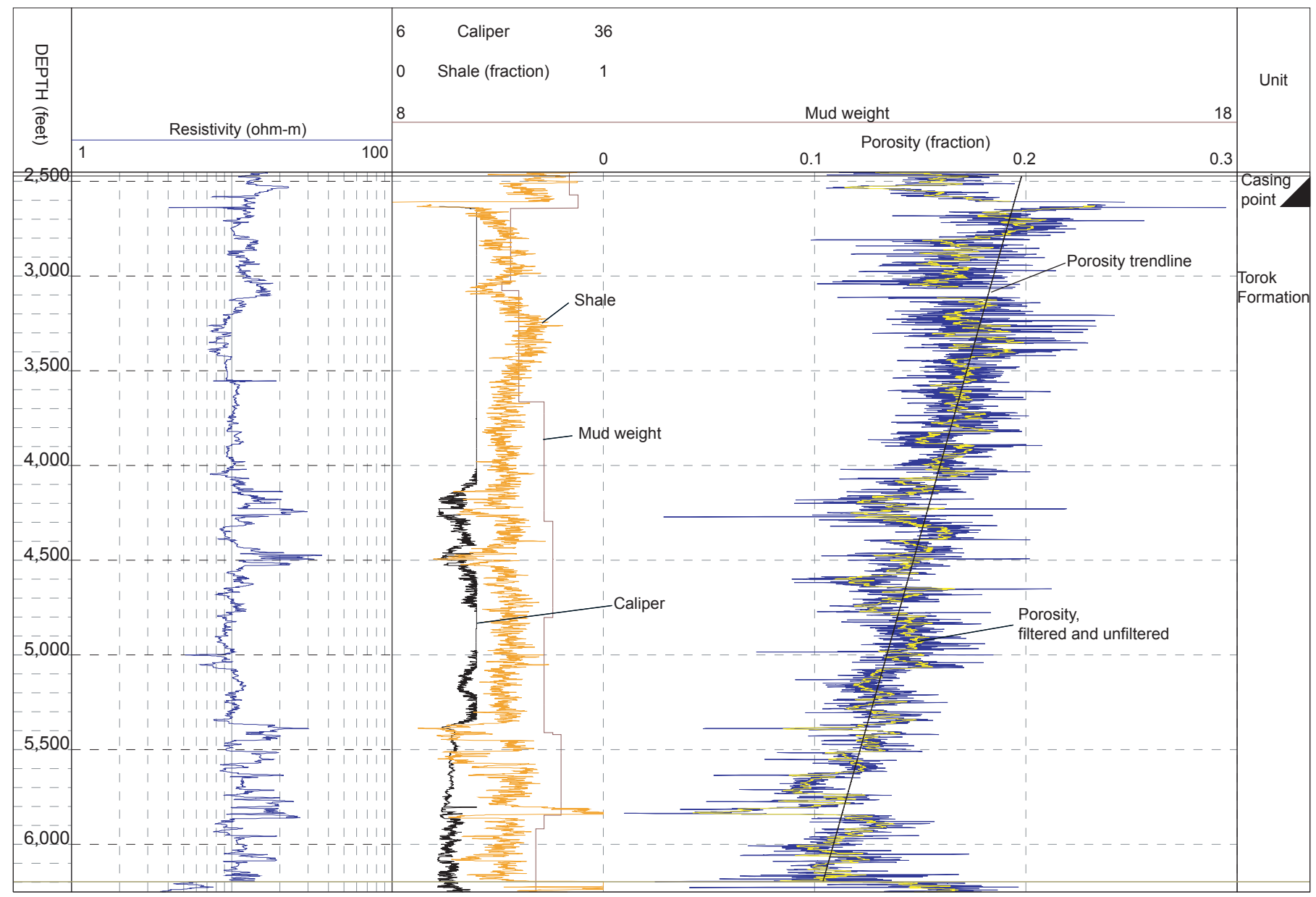

Figure 12.-Continued. 
during uplift. In any case, we attribute the mismatch between the porosity trendlines and Issler's (1992) trendlines in figure 14 to a combination of overpressure, which somehow produced the low porosity gradients, and uplift, which causes the (largely unaltered) steep trendlines to overlie the normal porosity gradients. For example, rapid deposition and subsidence in the Colville Trough may have led to overpressured conditions during the burial of Torok sedimentary deposits. Then uplift and erosion cause the porosity trendlines in figure 14 to plot at a shallow depth. The exact sequence of deposition, overpressuring, and uplift remains to be determined. Clearly, however, the porosities and porosity gradients differ among wells, and so the degree and spatial extent of overpressure must have varied throughout the basin.

The porosities listed in table 4, plotted in figures 13 and 14 as a function of depth, are plotted in figure 15 as porosity loss (the difference between porosity extrapolated to the top of the Torok Formation and the porosity at the base) versus the thickness of the Torok Formation. The Torok Formation is thickest and the porosity loss least in wells in the foothills (area G), and so the porosity gradients are lowest there, ranging from 0 to 2.3 percent per 1,000 ft. Data points for wells on the Barrow Arch east of Point Barrow (areas D, E) have porosity gradients ranging from 2.4 to 5.0 percent per 1,000 ft. In the Point Barrow area (area $\mathrm{C}$ ), porosity gradients range from 3.7 to 12.1 percent per 1,000 ft, and thicknesses are less than 3,500 ft. Thus, a continuum exists between low porosity gradients in the foothills, intermediate porosity gradients along the eastern part of the Barrow Arch, and high porosity gradients in the Point Barrow area.

\section{Porosity As a Function of Vitrinite Reflectance}

For each well, a relation between vitrinite reflectance, $R_{0}$, and depth $z$ was determined by using linear regression:

$$
\ln R_{0}=\ln a+b z,
$$

\section{$12 C$}

Kuyanak 1

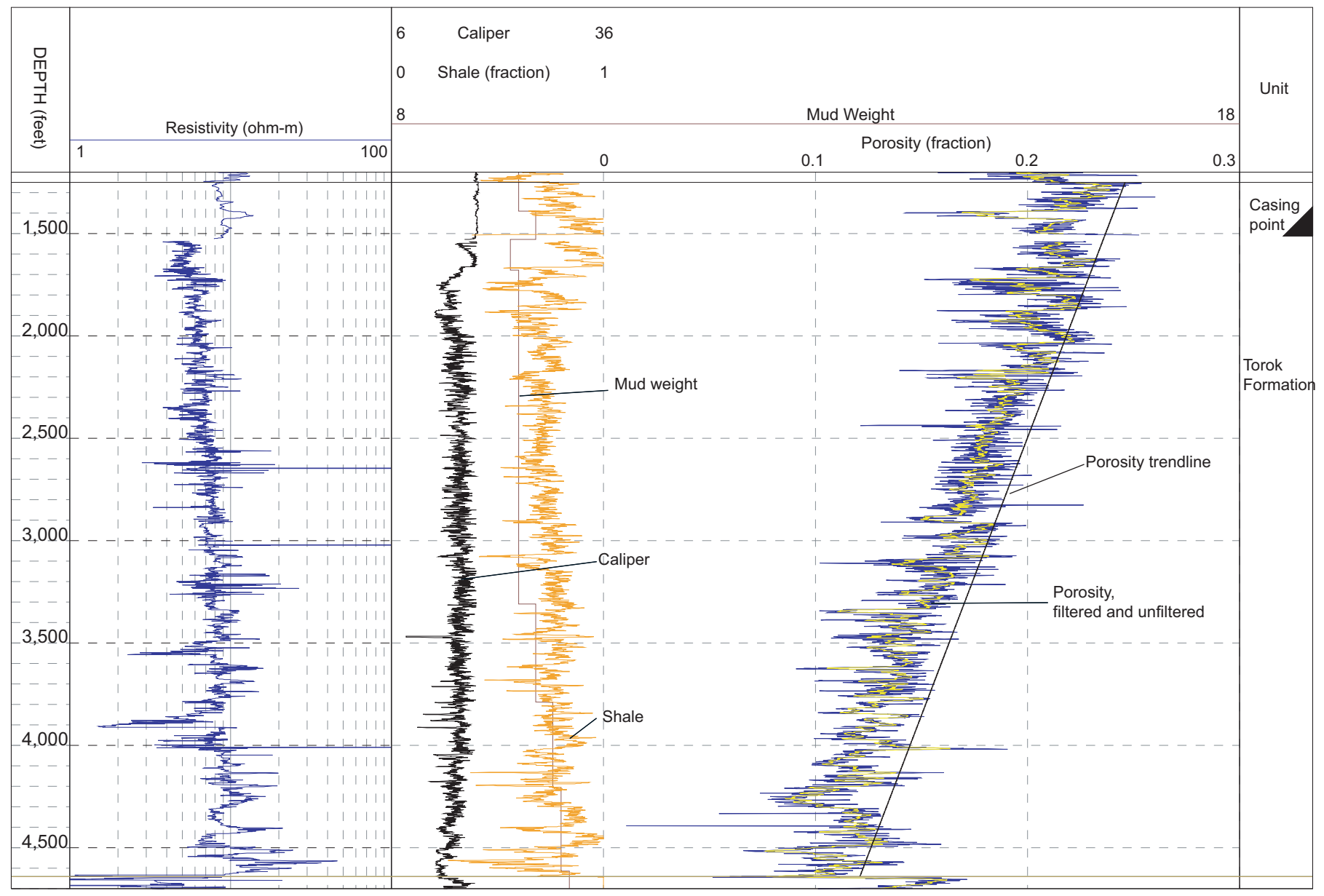

Figure 12.-Continued. 
where $a$ and $b$ are coefficients determined for each well. The coefficient $a$ represents the vitrinite reflectance extrapolated to the surface. In some wells, all the $R_{0}$ data from the well were used to establish $a$ and $b$ values for that well, and in other wells only data from the Torok Formation were used. $R_{0}$ data were available from most NPRA wells (for example, Johnsson and others, 1999); in a few wells, $a$ and $b$ values were determined from nearby wells. Using equation $6, R_{0}$ values were then determined at the top and bottom of the Torok Formation, so that the line segments for each well could be plotted in figures 16 and 17.

If porosity loss depended solely on thermal maturity and the $R_{0}$ data were free of systematic errors, then the line segments in figures 16 and 17 would collapse to a single bundle. The line segments do coalesce to some extent-plotting porosity as function of vitrinite reflectance (fig. 16) causes a tighter grouping of wells than plotting porosity as a function of depth (fig. 13) - but the coalescence of line segments within figure 16 or 17 is incomplete. Moreover, the line segments for wells in the foothills (fig. 17) lie below those in the coastal areas (fig. 16). As discussed in the preceding section, the rapid rate of sedimentation and overpressuring may be responsible for the preservation of porosity at greater depths in the foothills than in the coastal areas.

Three wells in the central area-Inigok, Koluktak, and Ikpikpuk (area F, fig. 1) - plot with low porosity gradients, similar to wells in the foothills area (figs. 13, 14), but, when plotted logarithmically against vitrinite reflectance in figure 17 , overlie the porosity trendlines for wells in the coastal areas. In other words, the $R_{0}$ data indicate thermal maturities in wells in the central area comparable to those in wells in the north, but the porosities and porosity gradients are more comparable to those in wells in the south. The overpressuring and effective stress in the central area apparently was similar to that in the foothills, but the depth of burial (and the uplift) was less.

The Tulaga well (area G, fig. 1) appears to be an isolated case. As calculated from the sonic log, the porosity in Torok shales is nearly constant at approximately 10.6 percent over the depth range 5,805-10,655 ft. However, vitrinite reflectances are low in comparison with similar porosities in deep

12D

J.W. Dalton 1

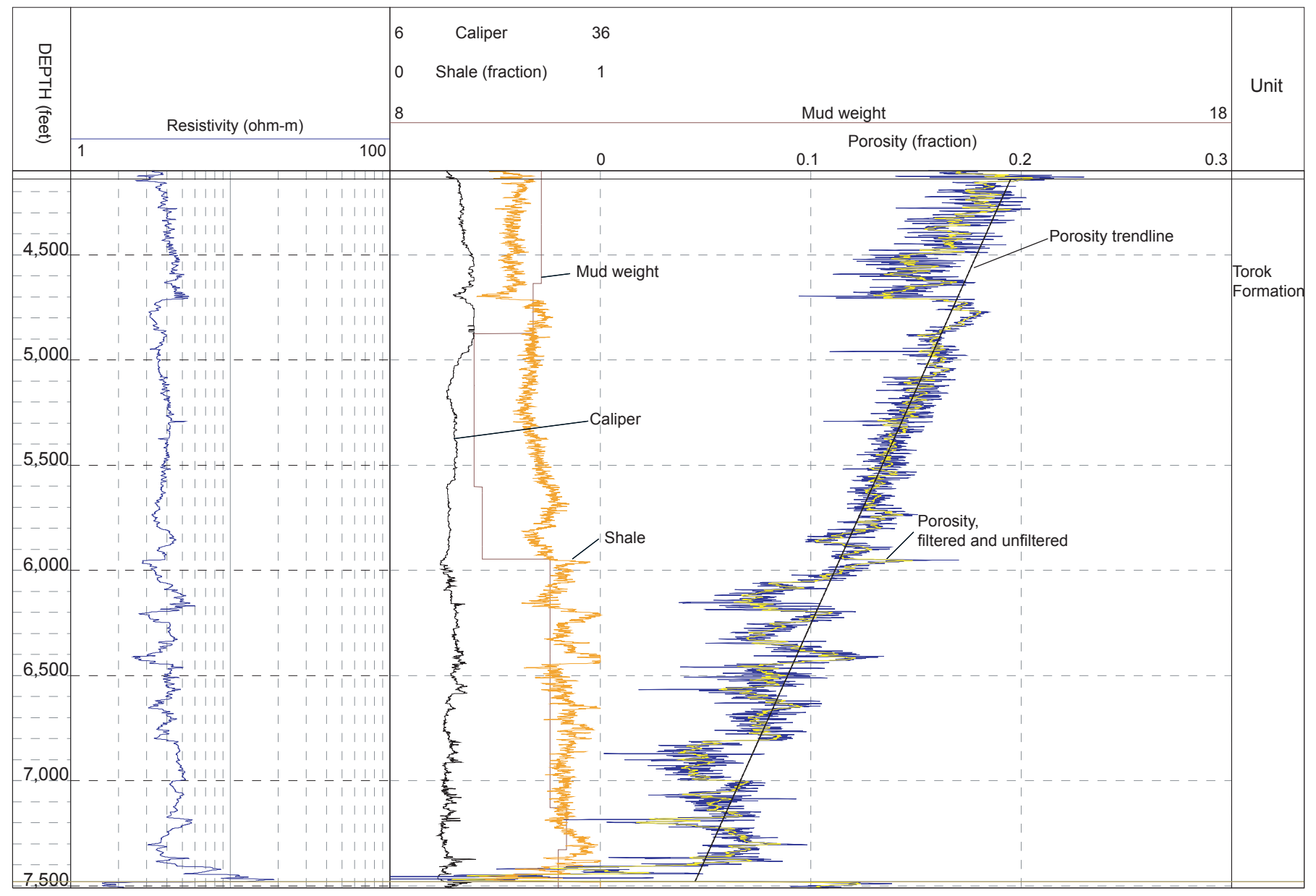

Figure 12.-Continued. 
wells in the foothills. Thus, the porosity trendline for the Tulaga well plots anomalously above the trendlines for all other wells in the foothills in figure 17. The porosities and their near-constancy with depth indicate that the Torok Formation was deeply buried, whereas the low vitrinite reflectances imply shallow burial (fig. 16). The consistency of the porosities with those in neighboring wells raises concern regarding the validity of the $R_{0}$ data from this well.

\section{Uplift}

As pointed out by Issler (1992), the offset of the porositydepth curves in figure 13 can be used to estimate the relative amount of uplift between any two wells. This offset can be calculated in three ways: (1) by extrapolating to the surface, (2) by extrapolating to zero porosity, or (3) by shifting the curves vertically and observing the displacement required to achieve an overlay. Because the third way is the least sensitive to errors in slope, we use it here. We calculated the uplift for all wells in the coastal area relative to the Phoenix well, the easternmost well in the study area (area E, fig. 1), which has a porosity-depth trend close to that of Issler's area 3, interpreted to mean that the uplift there has been negligible. In a separate evaluation of 12 offshore wells, the Phoenix well was observed to be one of 4 wells with no discernible uplift (Rowan and others, 2002). For wells in areas B through E (fig. 13), the uplift was calculated from the difference between the depth at which the porosity is 20 percent in a given well and the depth at which the porosity is 20 percent in the Phoenix well $(6,551 \mathrm{ft})$. The resulting values are mapped in figure 18 and listed in table 4.

In the foothills, western, and central areas, the porositydepth curves in figure 14 were shifted downward until they lay below Issler's line of no uplift. The resulting depth displacement is a minimum because the curves could be shifted deeper. The minimum uplifts determined for areas A, F, and $\mathrm{G}$ are mapped in figure 18 and listed in table 4.

Uplift (relative to the Phoenix well) ranges from 0 to $1,600 \mathrm{ft}$ within the extreme northeastern NPRA and immedi-

\section{$12 E$}

South Harrison Bay 1

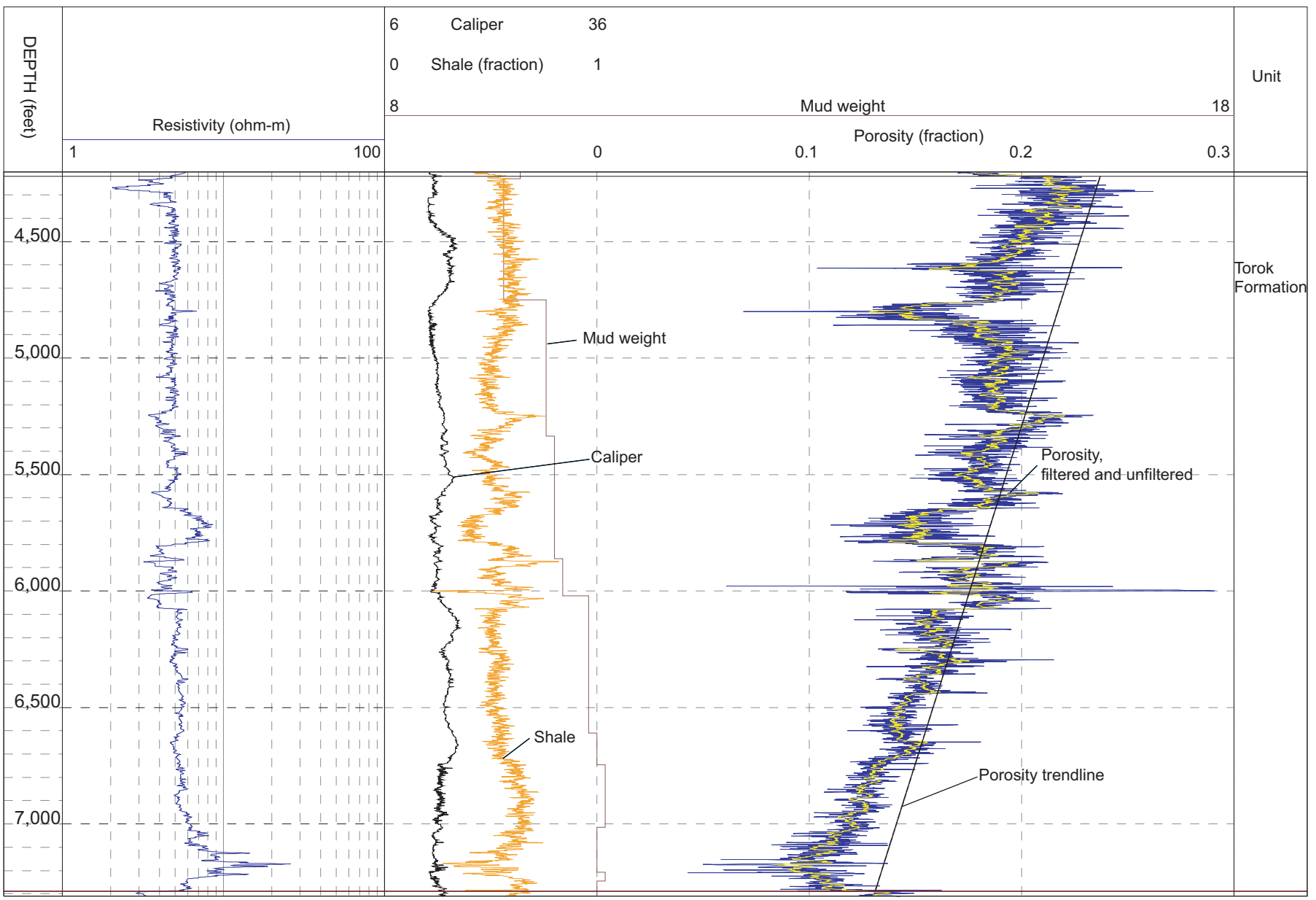

Figure 12.-Continued. 
ately offshore (area E, fig. 18), from 2,000 to 3,200 ft within the Simpson Shelf (area D), from 4,100 to 4,900 ft in the Point Barrow area (area C), and from 3,700 to $5,100 \mathrm{ft}$ in the area southwest of Point Barrow (area B). The maximum uplift of 5,100 ft occurs in the Brontosaurus well. Uplift increases steadily from east (area E) to west (area $\mathrm{C}$ and east end of area B) and then decreases at the west end of area B, as shown in figures 18 and 19 .

Four estimates of uplift from apatite fission-track analysis are directly comparable with our estimates of uplift from sonic logs. O'Sullivan (1999) calculated 3,900 ft of uplift and erosion in the Walakpa 1 well (area C, fig. 1), in comparison with our estimate of $4,800 \mathrm{ft}$. However, in the three other wells with both types of uplift estimate-Tunalik (area A), Inigok (area F), and Seabee (area G) — we calculated only minimum uplifts from porosity, which are less than, and thus compatible with, O'Sullivan's uplifts estimated from apatite fission-track data (fig. 18). Estimates of uplift in paired wells give a sense of relative error: East Simpson 1, 2,700 ft, and East Simpson 2, 3,000 $\mathrm{ft}$ (area D); Walakpa 1, 4,800 ft, and Walakpa 2, 4,800 ft (area C); and Tulageak, 4,600 ft, and West Dease, 4,000 ft (area C).

Three estimates of uplift by three different methods for wells along the Barrow Arch are compared in figure 19. The uplifts estimated from porosity are the same as those mapped in figure 18. The uplifts plotted on the west end of the red line are averages from the Peard and Kugrua wells (area B, fig. 1). The uplifts estimated from vitrinite reflectance are the elevations at which least-squares fits to the $R_{0}$ data extrapolate to a vitrinite reflectance of 0.25 . The uplift of 3,900 ft estimated from apatite fission-track data for the Walakpa 1 well (area C; O'Sullivan, 1999) is the lowest of the three estimates for that well. The uplifts estimated from vitrinite reflectance are comparable to the porosities estimated in eight wells but are greater by about $2,000 \mathrm{ft}$ than the porosities estimated in three wells. Despite these discrepancies, the uplifts estimated both from porosity and from vitrinite reflectance increase from east to west across the study area (fig. 1).

\section{$12 F$}

Phoenix

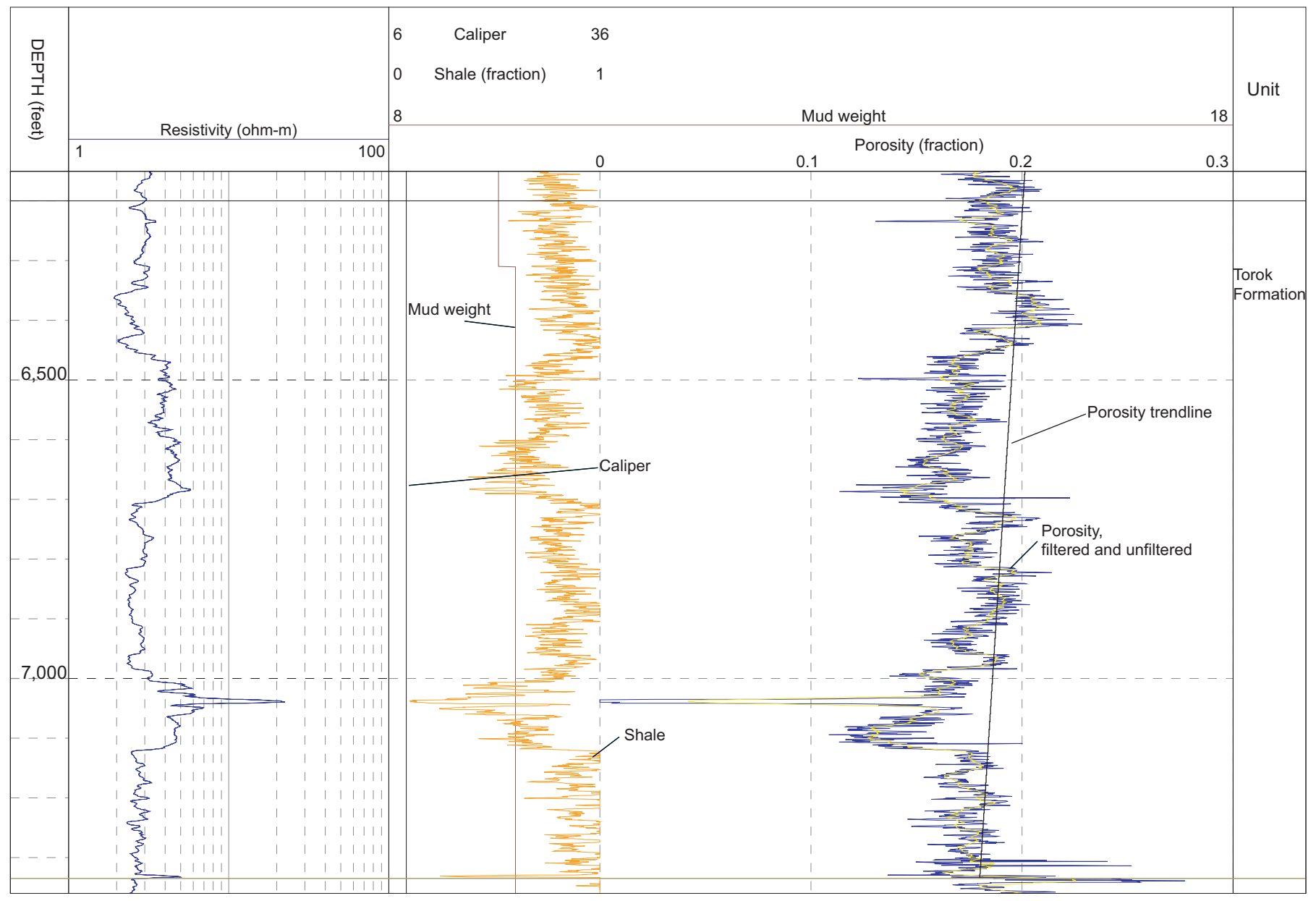

Figure 12.-Continued. 


\section{Summary and Conclusions}

By modifying the AFF equation to incorporate the shale fraction from the gamma-ray log, the porosity can be calculated from the sonic log for all siliciclastic rocks. Core data from NPRA wells indicate only a slight bias in the resulting estimates of porosity. On a plot of sonic velocity versus porosity, the AFF equation used in this report has a narrower window than some other transforms (Eberhart-Phillips and others, 1989; Vernik, 1997) but is comparable to the one developed for a wide range of datasets by Erickson and Jarrard (1998).

To examine compaction trends within the NPRA, we extracted a porosity-depth trend from the shaliest components of the Torok Formation. The decrease in porosity with depth in shales is approximately linear-at least, we could see no reason to apply a nonlinear trend to the porosity-depth data in the Torok Formation.
Porosity-depth trends in wells are grouped into seven areas, the characteristics of which are attributed to varying amounts of uplift and to the effect of overpressuring during burial in some parts of the NPRA. The porosity trendlines from various wells cluster better when plotted against vitrinite reflectance than against present-day depth, indicating that the use of $R_{0}$ data to compensate for maximum burial depth explains much, but not all, of the variation among compaction trends in the northern NPRA.

The record of uplift and erosion is clearly manifested in the porosity-depth trends in wells in the northern NPRA, where no record of overpressuring is evident. Using Issler's (1992) trendline of no uplift, we have determined uplifts ranging from 0 in the east to $5,100 \mathrm{ft}$ in the west. South of the Barrow Arch, the rocks have been sufficiently compacted that the estimates of uplift are minimums rather than totals. The largest minimum uplift was determined in the East Kurupa well (area G, fig. 1), where at least 5,700 ft of uplift has occurred.

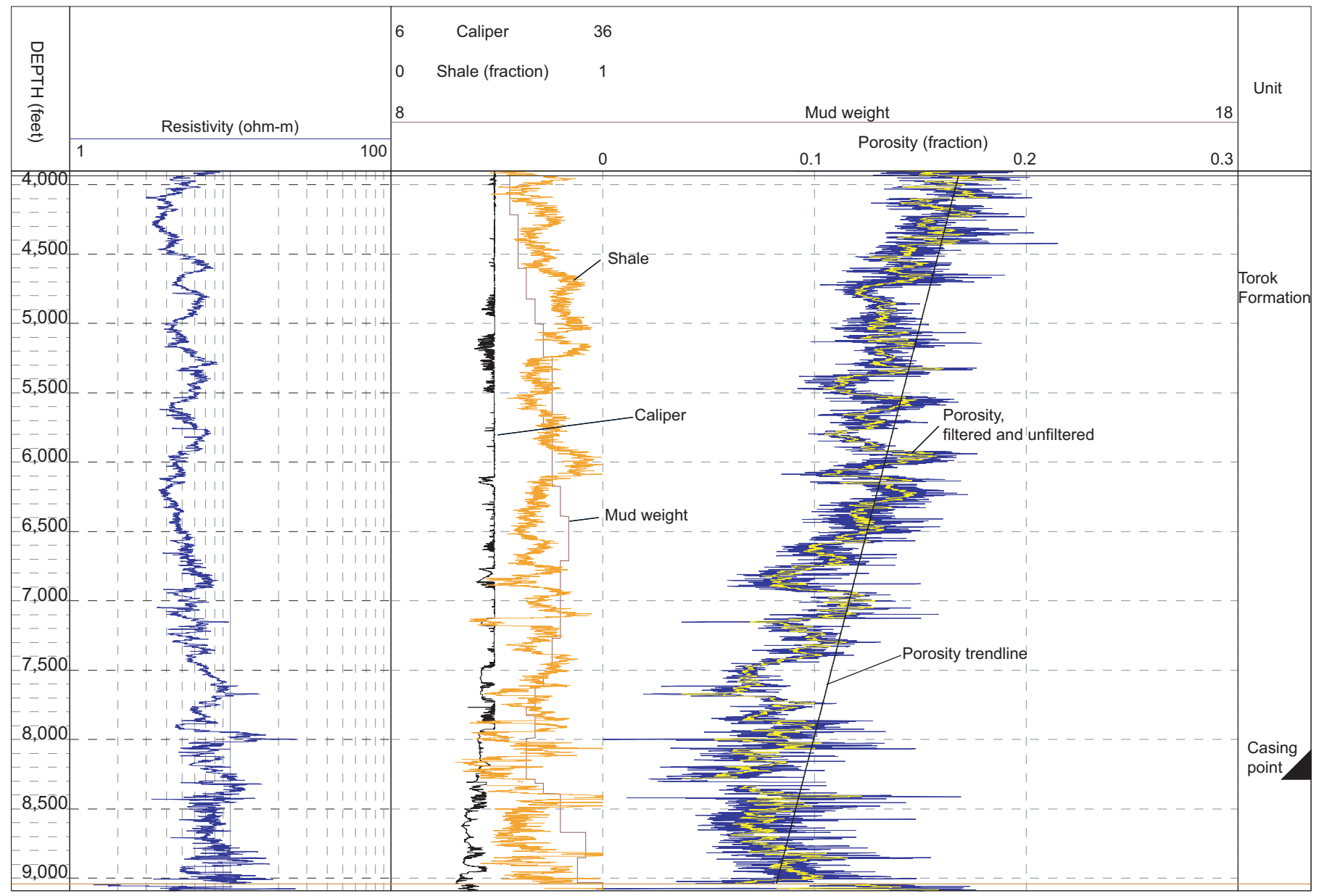

Figure 12.-Continued. 
$12 H$ Tulugak 1

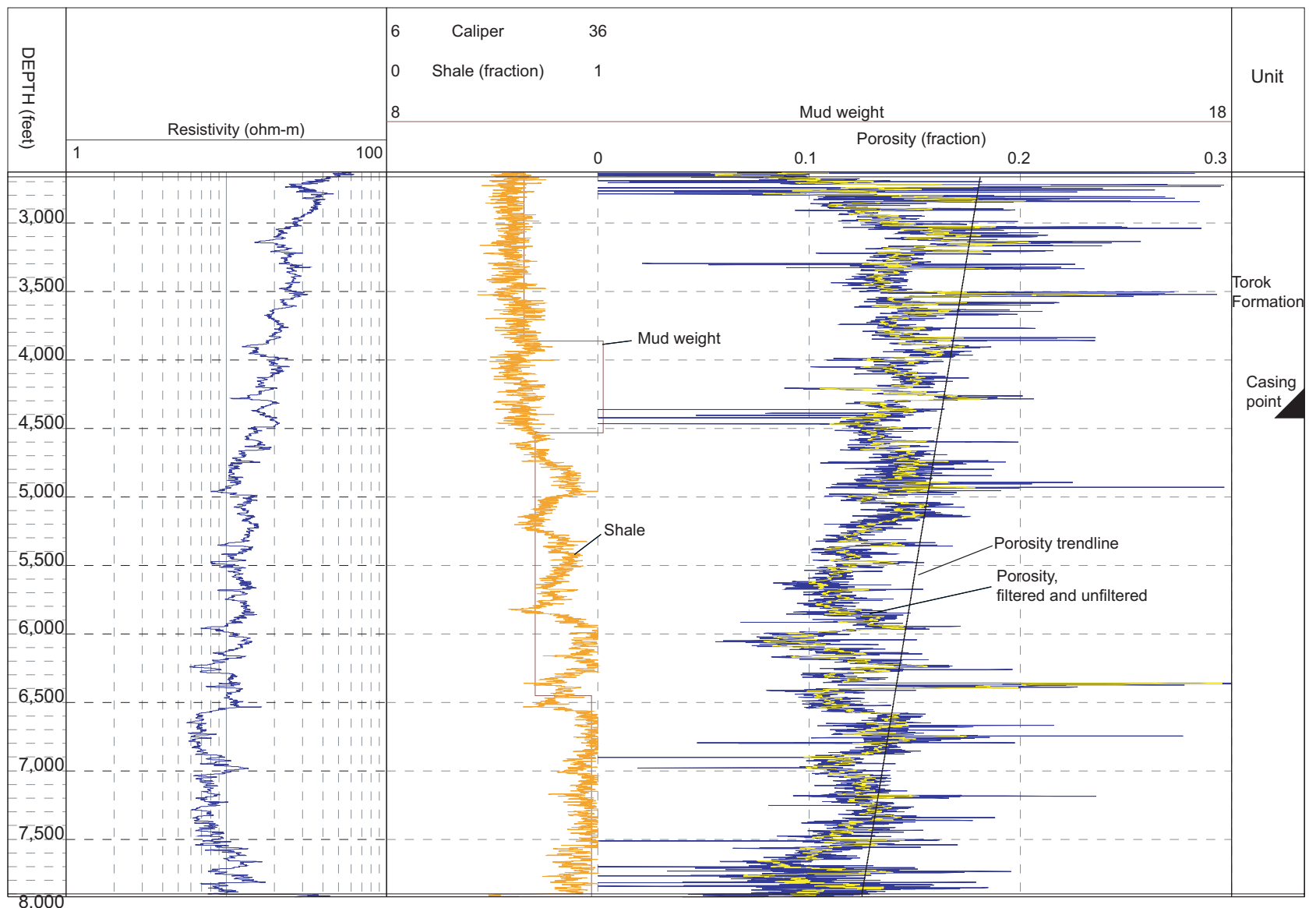

Figure 12.-Continued.

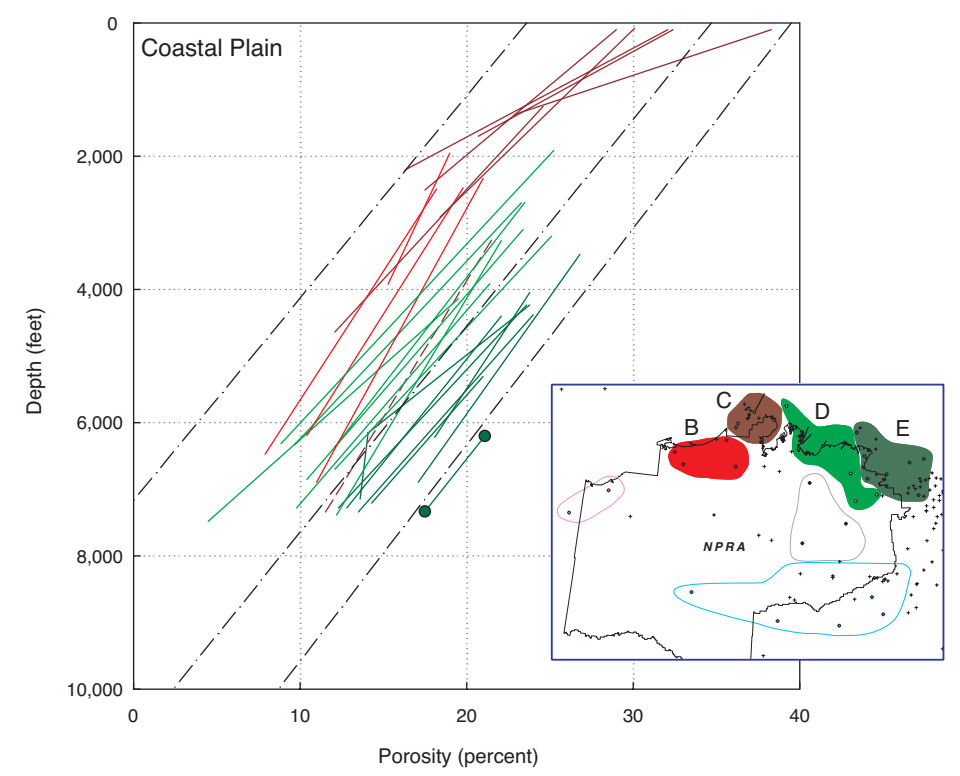

Figure 13. Average porosity in shales versus depth within the Torok Formation in wells drilled in coastal areas and offshore of the National Petroleum Reserve in Alaska (NPRA) (areas B-E, fig. 1), with porositydepth trendlines (dashed curves) determined by Issler (1992) for areas 3 through 5 in the Beaufort-Mackenzie Basin, northwestern Canada (fig. 3), shown for comparison. Short line terminated by circles is porosity-depth curve for the Phoenix well. 


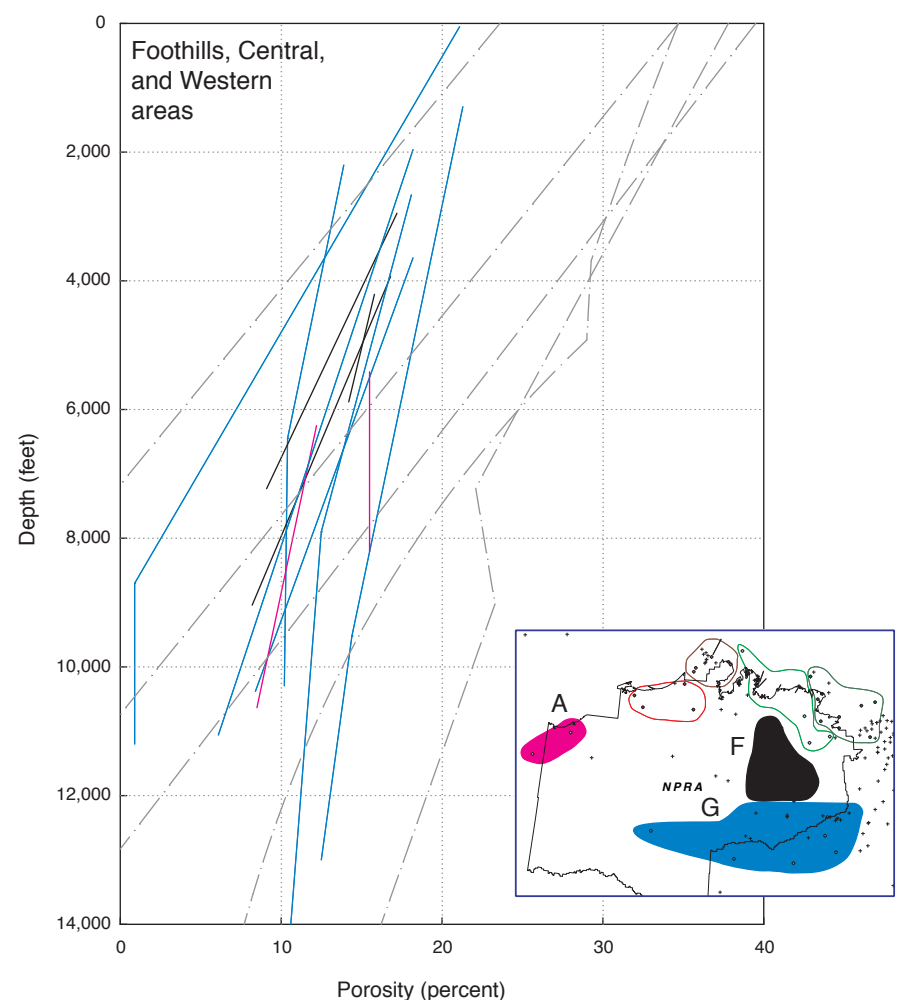

Figure 14. Average porosity in shales versus depth within the Torok Formation in wells drilled in foothills and central and western areas of the National Petroleum Reserve in Alaska (areas G, F, and A, respectively, fig. 1), with porosity-depth trendlines (dashed curves) determined by Issler (1992) for areas 1 through 5 in the Beaufort-Mackenzie Basin, northwestern Canada (fig. 3), shown for comparison.

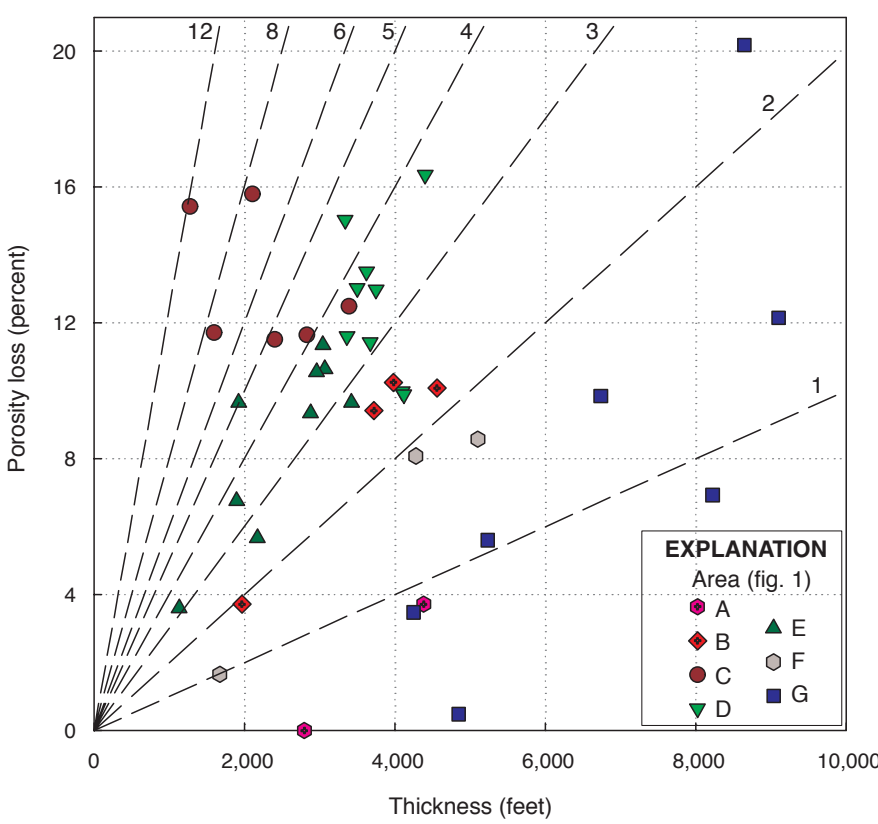

Figure 15. Porosity loss in shales from top to bottom of the Torok Formation versus thickness of the Torok Formation in wells drilled in areas $A$ through G, National Petroleum Reserve in Alaska (see fig. 1 for locations and table 2 for well data). Each data point represents porosity loss and formation thickness in an individual well; lower segments of two-part linear fit in five wells (Awuna, Antares, East Kurupa, Seabee, and Tulugak) are omitted. Numbered dashed curves, porosity-loss gradients, ranging from 1 to 12 percent per 1,000 ft; in comparison, porosity gradient determined by Issler (1992) for area 3 of the Beaufort-Mackenzie Basin, northwestern Canada (fig. 3 ), is 3.1 percent per 1,000 ft.

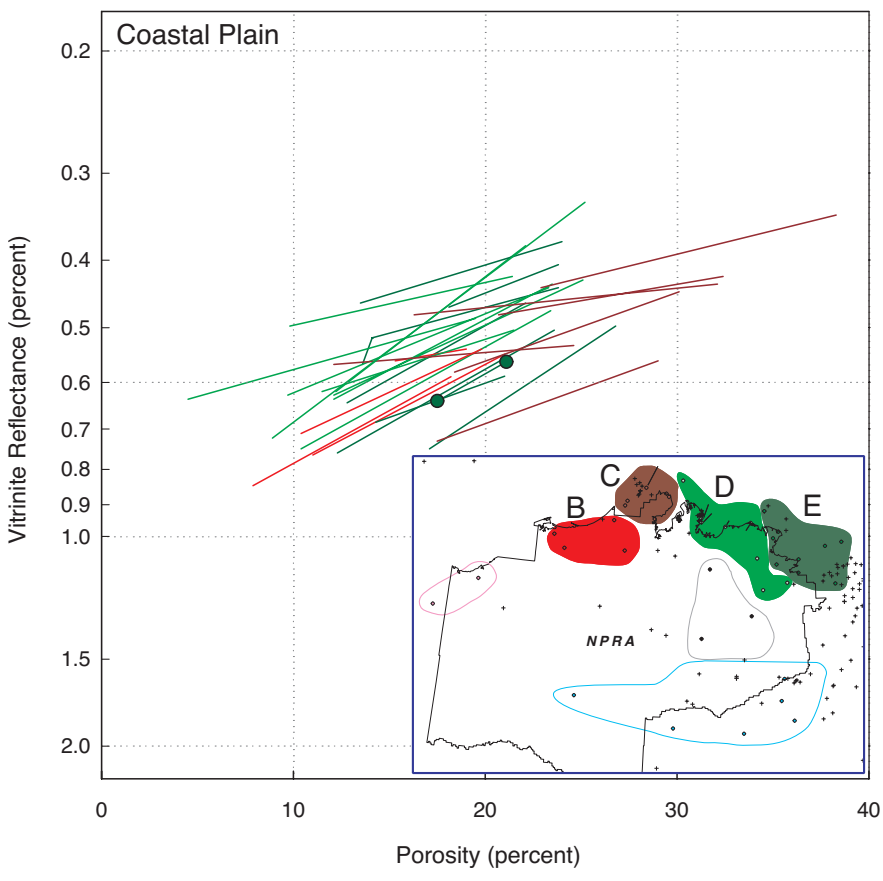

Figure 16. Average porosity in shales versus vitrinite reflectance in wells drilled in coastal areas of the National Petroleum Reserve in Alaska (NPRA) (areas B-E, fig. 1). Short line terminated by circles is porosity-vitrinite reflectance curve for the Phoenix well. 
Table 4. Porosities and estimated uplift in the Torok and lower Torok Formations.

[Five wells are fitted with two straight lines (upper and lower), spanning the Torok and lower Torok Formations. Top depth is top of the Torok Formation; bottom depth is bottom of the Torok Formation or bottom of the lower Torok Formation, if present]

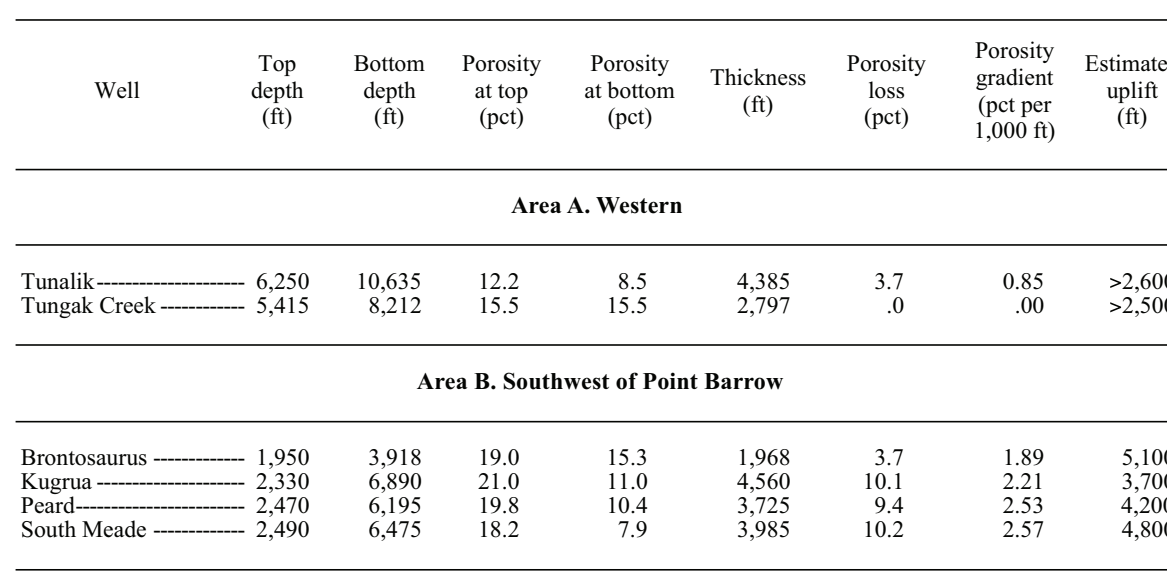

\begin{tabular}{|c|c|c|c|c|c|c|c|c|}
\hline \multicolumn{9}{|c|}{ Area C. Point Barrow } \\
\hline Kuyanak - & 1,250 & 4,640 & 24.6 & 12.1 & 3,390 & 12.5 & 3.68 & 4,100 \\
\hline South Barrow 18 & 98 & 1,375 & 38.3 & 22.9 & 1,277 & 15.4 & 12.08 & 4,900 \\
\hline 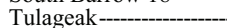 & 100 & 2,505 & 29.0 & 17.5 & 2,405 & 11.5 & 4.79 & 4,600 \\
\hline Walakpa 1 & 101 & 1,700 & 32.4 & 20.7 & 1,599 & 11.7 & 7.33 & 4,800 \\
\hline Walakpa 2 & 98 & 2,205 & 32.1 & 16.3 & 2,107 & 15.8 & 7.50 & 4,800 \\
\hline West Dease - & 80 & 2,910 & 30.1 & 18.4 & 2,830 & 11.7 & 4.12 & 4,000 \\
\hline
\end{tabular}

\begin{tabular}{|c|c|c|c|c|c|c|c|}
\hline \multicolumn{8}{|c|}{ Area D. Simpson Shelf } \\
\hline Cabot 3,256 & 7,352 & 21.5 & 11.5 & 4,096 & 10.0 & 2.44 & 2,700 \\
\hline Drew Point-_ 3,200 & 6,700 & 25.1 & 12.1 & 3,500 & 13.0 & 3.72 & 2,000 \\
\hline East Simpson 1 2, 2,690 & 6,365 & 23.5 & 12.1 & 3,675 & 11.4 & 3.11 & 2,700 \\
\hline East Simpson 2 - 2,700 & 6,325 & 23.3 & 9.7 & 3,625 & 13.5 & 3.73 & 3,000 \\
\hline East Teshekpuk - 3,100 & 6,850 & 23.4 & 10.4 & 3,750 & 13.0 & 3.46 & 2,500 \\
\hline J.W. Dalton - & 7,480 & 19.5 & 4.5 & 3,340 & 15.0 & 4.50 & 2,500 \\
\hline North Inigok--_- 3,265 & 7,385 & 22.1 & 12.2 & 4,120 & 9.9 & 2.40 & 2,400 \\
\hline South Simpson--_- 1,910 & 6,315 & 25.2 & 8.9 & 4,405 & 16.4 & 3.71 & 3,200 \\
\hline West Fish Creek - & 7,280 & 21.4 & 9.8 & 3,365 & 11.6 & 3.45 & 2,200 \\
\hline
\end{tabular}

\begin{tabular}{|c|c|c|c|c|c|c|c|}
\hline \multicolumn{8}{|c|}{ Area E. Northeastern } \\
\hline 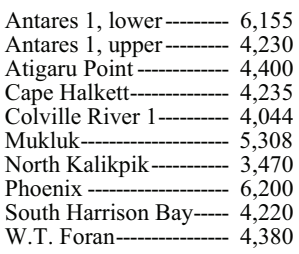 & $\begin{array}{l}7,142 \\
6,155 \\
7,280 \\
7,280 \\
6,219 \\
7,204 \\
6,895 \\
7,335 \\
7,290 \\
7,340\end{array}$ & $\begin{array}{l}14.1 \\
23.8 \\
22.1 \\
23.6 \\
23.8 \\
21.0 \\
26.8 \\
21.1 \\
23.7 \\
24.0\end{array}$ & $\begin{array}{l}13.6 \\
14.1 \\
12.8 \\
12.3 \\
18.1 \\
14.3 \\
17.1 \\
17.5 \\
13.1 \\
13.5\end{array}$ & $\begin{array}{r}987 \\
1,925 \\
2,880 \\
3,045 \\
2,175 \\
1,896 \\
3,425 \\
1,135 \\
3,070 \\
2,960\end{array}$ & $\begin{array}{r}0.5 \\
9.7 \\
9.4 \\
11.4 \\
5.7 \\
6.8 \\
9.7 \\
3.6 \\
10.6 \\
10.6\end{array}$ & $\begin{array}{l}0.51 \\
5.01 \\
3.25 \\
3.73 \\
2.60 \\
3.57 \\
2.82 \\
3.19 \\
3.47 \\
3.57\end{array}$ & $\begin{array}{r}-- \\
1,600 \\
1,500 \\
1,300 \\
1,100 \\
900 \\
700 \\
0 \\
1,300 \\
1,000\end{array}$ \\
\hline \multicolumn{8}{|c|}{ Area F. Central } \\
\hline 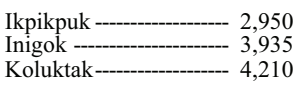 & $\begin{array}{l}7,230 \\
9,040 \\
5,882\end{array}$ & $\begin{array}{l}17.2 \\
16.8 \\
15.8\end{array}$ & $\begin{array}{r}9.1 \\
8.2 \\
14.2\end{array}$ & $\begin{array}{l}4,280 \\
5,105 \\
1,672\end{array}$ & $\begin{array}{l}8.1 \\
8.6 \\
1.7\end{array}$ & $\begin{array}{l}1.89 \\
1.68 \\
0.99\end{array}$ & $\begin{array}{l}>4,200 \\
>3,200 \\
>3,300\end{array}$ \\
\hline \multicolumn{8}{|c|}{ Area G. Foothills } \\
\hline $\begin{array}{lr}\text { Awuna, lower ----------- } & 8,700 \\
\text { Awuna, upper ---------- } & 50 \\
\text { Big Bend-------------- } 3,642 \\
\text { East Kurupa, lower ---- } 6,450 \\
\text { East Kurupa, upper ---- 2,200 } \\
\text { Seabee, lower----------- 9,520 } \\
\text { Seabee, upper--------- 1,295 } \\
\text { Tulaga ----------------5,805 } \\
\text { Tulugak, lower-------- 7,900 } \\
\text { Tulugak, upper--------- 2,665 } \\
\text { West Kurupa---------- 1,960 }\end{array}$ & $\begin{array}{r}11200 \\
8,700 \\
10,380 \\
10,294 \\
6,450 \\
13,000 \\
9,520 \\
10,655 \\
15,960 \\
7,900 \\
11,060\end{array}$ & $\begin{array}{r}0.9 \\
21.1 \\
18.2 \\
10.4 \\
13.9 \\
14.4 \\
21.3 \\
10.9 \\
12.5 \\
18.1 \\
18.2\end{array}$ & $\begin{array}{r}0.9 \\
0.9 \\
8.4 \\
10.2 \\
10.4 \\
12.5 \\
14.4 \\
10.4 \\
10.0 \\
12.5 \\
6.1\end{array}$ & $\begin{array}{l}2,500 \\
8,650 \\
6,738 \\
3,844 \\
4,250 \\
3,480 \\
8,225 \\
4,850 \\
8,060 \\
5,235 \\
9,100\end{array}$ & $\begin{array}{r}0.0 \\
20.2 \\
9.8 \\
.2 \\
3.5 \\
1.9 \\
6.9 \\
.5 \\
2.5 \\
5.6 \\
12.2\end{array}$ & $\begin{array}{r}0.00 \\
2.33 \\
1.46 \\
.06 \\
.82 \\
.54 \\
.84 \\
.10 \\
.31 \\
1.07 \\
1.34\end{array}$ & $\begin{array}{r}-- \\
>5,600 \\
>3,200 \\
--- \\
>5,700 \\
--- \\
>4,600 \\
>3,500 \\
-- \\
>4,200 \\
>4,800\end{array}$ \\
\hline
\end{tabular}


Porosity gradients range from 1 percent per $1,000 \mathrm{ft}$ in the foothills, where the Torok section is thickest and burial has been deepest, to 12 percent per 1,000 ft in the Point Barrow area, where the section is thinnest (fig. 15). This range in porosity gradient is greater than that reported in other studies, such as by Issler (1992). The determination of its cause awaits further investigation of burial history across the basin to resolve the effects of sedimentation rate and overpressuring.

\section{References Cited}

Bartsch-Winkler, S.B., and Huffman, A.C., 1988, Sandstone petrography of the Nanushuk Group and Torok Forma- tion, in Gryc, George, ed., Geology and exploration of the National Petroleum Reserve in Alaska, 1974 to 1982: U.S. Geological Survey Professional Paper 1399, p. 801-831.

Eberhart-Phillips, D.M., Han, D.H., and Zoback, M.D., 1989, Empirical relationships among seismic velocity, effective pressure, porosity, and clay content in sandstone: Geophysics, v. 54, no. 1, p. 82-89.

Erickson, S.N., and Jarrard, R.D., 1998, Velocity-porosity relationships for water-saturated siliciclastic sediments, Journal of Geophysical Research, v. 103, no. B12, p. 30385-30406.

Harrold, T.W.D., Swarbrick, R.E., and Goulty, N.R., 1999, Pore pressure estimation from mudrock porosities in

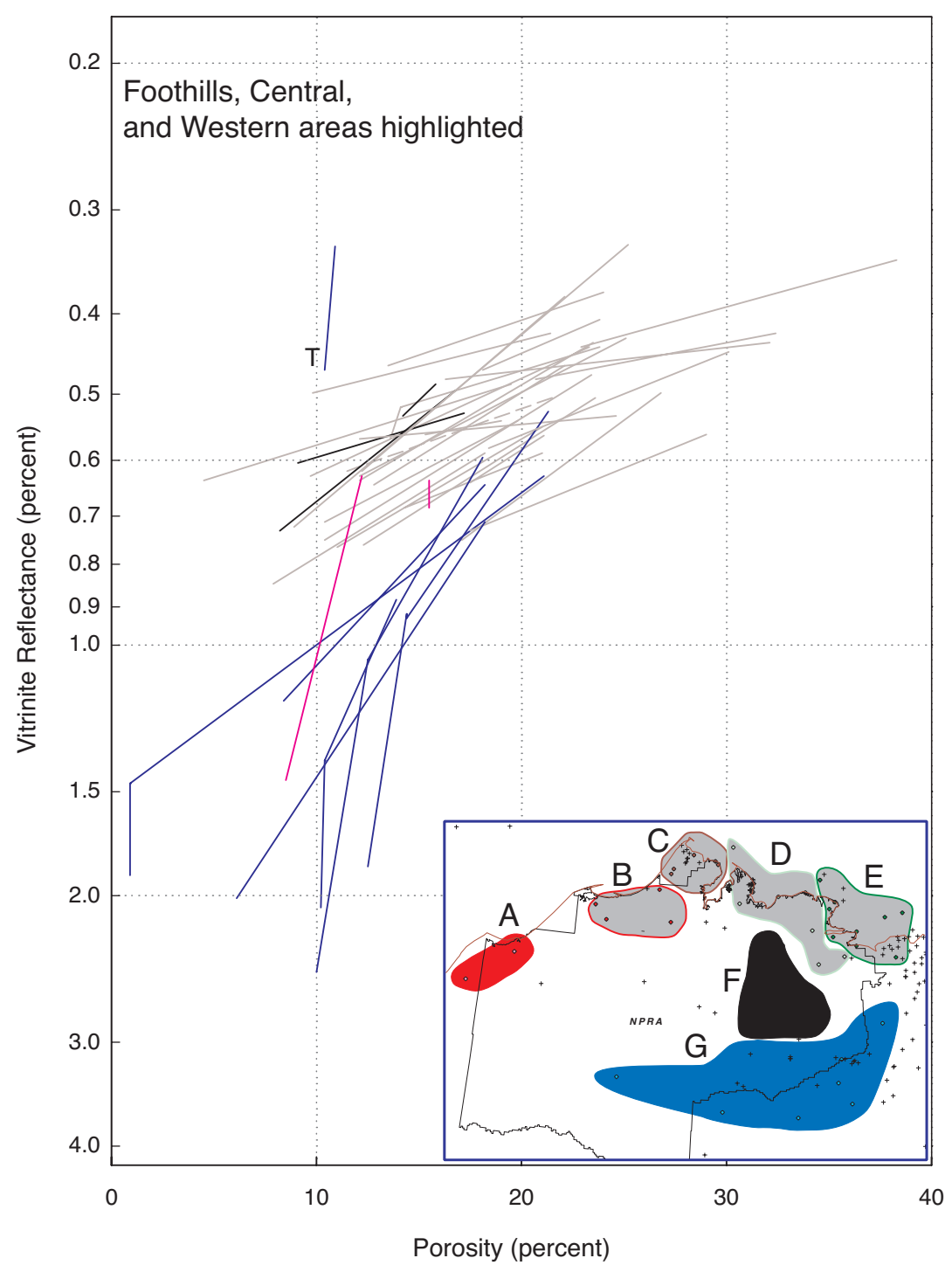

Figure 17. Average porosity in shales versus vitrinite reflectance in wells drilled in foothills and central and western areas of the National Petroleum Reserve in Alaska (NPRA) (areas G, F, and A, respectively, fig. 1), with porosity trendlines (gray curves) for coastal areas from figure 14 shown for comparison. Line $T$ is for the Tulaga well in northeast corner of area $\mathrm{G}$. 
Tertiary basins, southeast Asia: American Association of Petroleum Geologists Bulletin, v. 83, no. 7, p. 10571067.

Hearst, J.R, Nelson, P.H., and Paillet, F.L., 2000, Well logging for physical properties; a handbook for geophysicists, geologists, and engineers ( $2 \mathrm{~d}$ ed.): Chichester, U.K., J. Wiley, 483 p.

Hunt, J.M., Whelan, J.K., Eglinton, L.B., and Cathles, L.M., III, 1998, Relation of shale porosities, gas generation, and compaction to deep overpressures in the U.S. Gulf Coast, in Law, B.E., Ulmishek, G.F., and Slavin, V.I., eds., Abnormal pressures in hydrocarbon environments: American Association of Petroleum Geologists Memoir 70, p. 87-104.

Issler, D.R., 1992, A new approach to shale compaction and stratigraphic restoration, Beaufort-Mackenzie Basin and Mackenzie Corridor, northern Canada: American Association of Petroleum Geologists Bulletin, v. 76, no. 8, p. $1170-1189$.

Johnsson, M. J., Evans, K.R., and Marshall, H.A. 1999, Thermal maturity of sedimentary rocks in Alaska; digital resources: U.S. Geological Survey Digital Data Series DDS-54, CD-ROM [URL http://wrgis.wr.usgs.gov/dds/ dds-54/Data/].

Magara, Kinji, 1978, Compaction and fluid migration; practical petroleum geology (Developments in Petroleum Science, no. 9), Amsterdam, Elsevier, 319 p.

Molenaar, C.M., 1988, Depositional history and seismic stratigraphy of Lower Cretaceous rocks in the National Petroleum Reserve in Alaska and adjacent areas, in Gryc, George, ed., Geology and exploration of the National Petroleum Reserve in Alaska, 1974 to 1982: U.S. Geological Survey Professional Paper 1399, p. 593-621.

Mull, C.G., Houseknecht, D.W., and Bird, K.J., 2003, Revised Cretaceous and Tertiary stratigraphic nomenclature in the Colville basin, northern Alaska: U.S. Geological Survey Professional Paper 1673 [URL http://pubs. usgs.gov/pp/p1673/text.html].

O’Sullivan, P.B., 1999, Thermochronology, denudation and variations in paleosurface temperature; a case study from the North Slope foreland basin, Alaska: Basin Research, v. 11 , no. 3, p. 191-204.

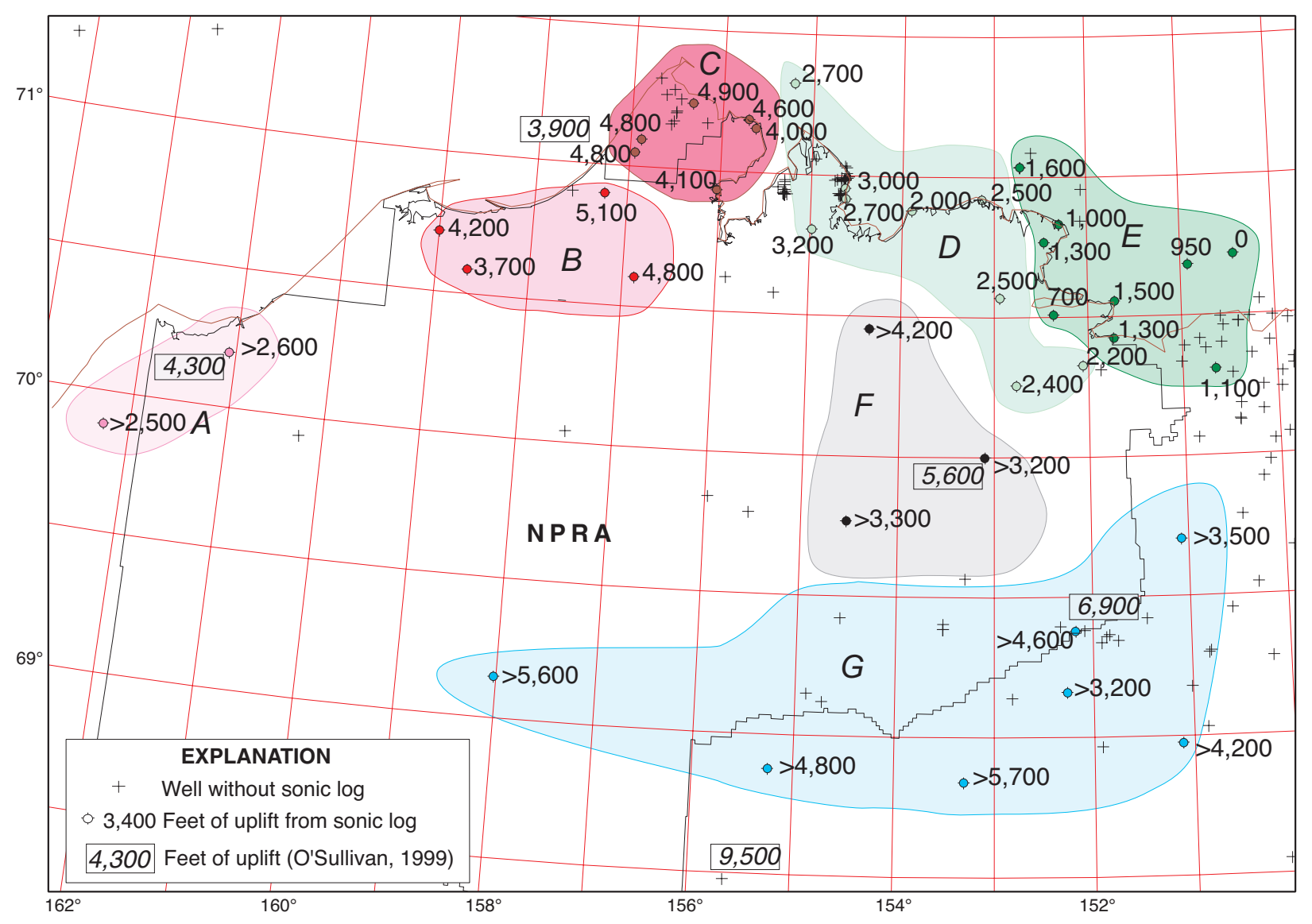

Figure 18. National Petroleum Reserve in Alaska (NPRA), showing uplift (in feet) estimated from porosity trends calculated from sonic logs in wells (see fig. 1 for locations and table 2 for well data). 
Potter, C.J., and Moore, T.E., 2003, Brookian structural plays in the National Petroleum Reserve-Alaska: U.S. Geological Survey Open-File Report 03-266 [URL http://pubs.usgs.gov/of/2003/of03-266/].

Raiga-Clemenceau, Jean, Martin, J.P., and Nicoletis, Serge, 1988, The concept of acoustic formation factor for more accurate porosity determination from sonic transit time data: Log Analyst, v. 29, no. 1, p. 54-60.

Rowan, E.L., Hayba, D.O., Nelson, P.H., Burns, W.M., and Houseknecht, D.W., 2003, Sandstone and shale compaction curves derived from sonic and gamma ray logs in offshore wells, North Slope, Alaska-parameters for basin modeling: U.S. Geological Survey Open-File Report 03-329, 3 sheets.

Rowan, E.L., Nelson, P.H., and Hayba, D.O., 2002,
Compaction properties of sandstones and shales in the National Petroleum Reserve, Alaska (NPRA) — significance for burial and thermal history models [abs.]: American Association of Petroleum Geologists Bulletin, v. 86, no. 6, p. 1158 .

Vernik, Lev, 1997, Predicting porosity from acoustic velocities in siliciclastics; a new look: Geophysics, v. 62, no. 1, p. 118-128.

Vernik, Lev, and Nur, Amos, 1992, Petrophysical classification of siliciclastics for lithology and porosity prediction from seismic velocities: American Association of Petroleum Geologists Bulletin, v. 76, no. 9, p. 1295-1309.

Wylie, M.R.J., Gregory, A.F., and Gardner, L.W., 1956, Elastic wave velocities in heterogeneous and porous media: Geophysics, v. 21, p. 41-70.

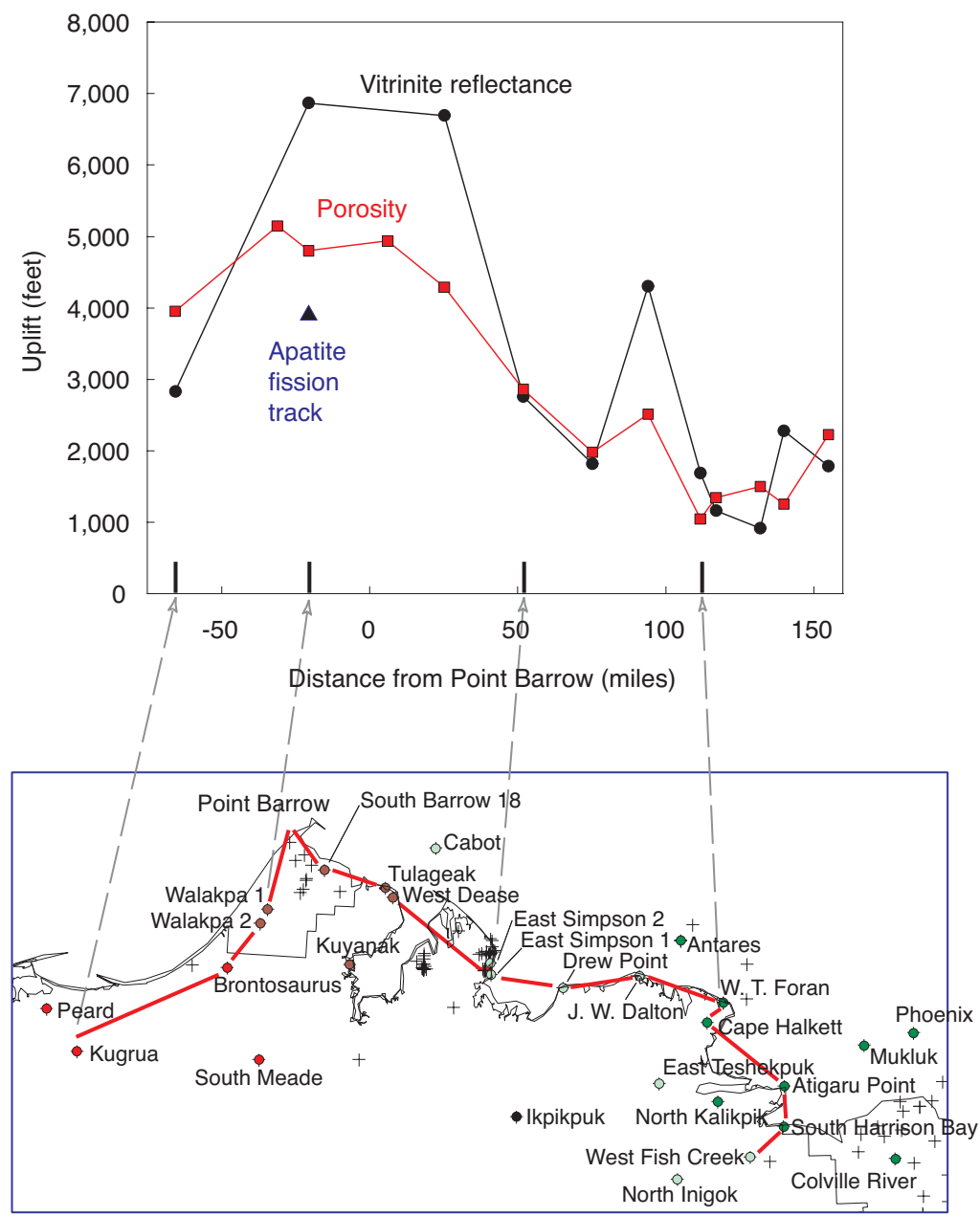

Figure 19. Uplift along the Barrow Arch (fig. 1) estimated by three different methods: vitrinite reflectance, porosity trends calculated from sonic logs, and apatite fission-track analysis. Circles, wells with sonic logs; crosses, wells without sonic logs. 